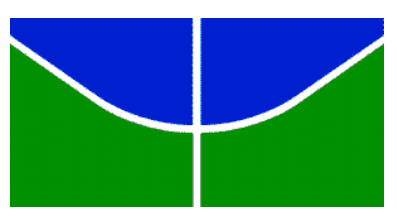

UNIVERSIDADE DE BRASÍLIA

FACULDADE DE AGRONOMIA E MEDICINA VETERINÁRIA

DESEMPENHO E CARCATERÍSTICAS DA CARCAÇA E DA CARNE DE CORDEIROS DE DIFERENTES GRUPOS GENÉTICOS

LUANA FROSSARD GOMES DE AGUIAR

ORIENTADOR: CLAYTON QUIRINO MENDES

DISSERTAÇÃO DE MESTRADO EM CIÊNCIAS ANIMAIS

PUBLICAÇÃO: 133/2015

BRASÍLIA/DF

JULHO DE 2015 


\section{UNIVERSIDADE DE BRASÍLIA \\ FACULDADE DE AGRONOMIA E MEDICINA VETERINÁRIA}

DESEMPENHO E CARACTERÍSTICAS DA CARCAÇA E DA CARNE DE

CORDEIROS DE DIFERENTES GRUPOS GENÉTICOS

DISSERTAÇÃO DE MESTRADO SUBMETIDA AO PROGRAMA DE PÓS-GRADUACAÇÃO EM CIÊNCIAS ANIMAIS, COMO PARTE DOS REQUISITOS PARA OBTENÇÃO DE GRAU DE MESTRE EM CIÊNCIAS ANIMAIS.

APROVADA POR:

CLAYTON QUIRINO MENDES

(Orientador)

RODRIGO VIDAL OLIVEIRA

(Examinador Interno)

DANIELA BRANDÃO OLIVEIRA

(Examinador Externo)

BRASÍLIA/DF, 08 de julho de 2015. 
DEDICATÓRIA

"Dedico esta dissertação primeiramente a Deus por todas as graças recebidas, aos meus pais, meu orientador Clayton Mendes e ao professor Rodrigo Vidal pela contribuição e confiança em minha competência." 


\section{AGRADECIMENTOS}

Agradeço primeiramente a Deus que sempre iluminou o meu caminho, a Virgem Mãe de Deus com todos os seus Santos e Anjos pelas infinitas interseções e proteções.

A minha maravilhosa mãe por toda dedicação, apoio e conselhos nos momentos de aflição e principalmente por acreditar no meu potencial. Ao meu pai, que sempre incansável investiu nos meus estudos e na minha formação acadêmica, todo o seu apoio foi de extrema importância para a minha formação profissional.

A minha irmã por toda paciência e apoio nos momentos mais difíceis, sempre me mostrando a ter discernimento e a seguir melhor caminho.

Ao meu orientador professor Clayton Quirino Mendes por todo apoio e dedicação. Ao professor e amigo Rodrigo Vidal, por toda a paciência, apoio, amizade, dedicação ao trabalho, e principalmente pelo aprendizado durante todo o período do estudo, o qual foi essencial para o meu crescimento pessoal e profissional.

Aos mestres e amigos professores Sérgio e Diogo pela excelente contribuição no estudo e disposição para me auxiliar nos momentos mais difíceis.

Aos meus amigos Isadora, Nina, Eduardo, Jânio, Camille, Jara, Luíz Fernando, Sávio, Fernanda, Karolliny pela sincera amizade e incansável apoio no experimento e ainda nos momentos de diversão. Aos nobres amigos e colegas de trabalho Antônio, Romilson, Franklin pela consideração e respeito.

A Daniela Brandão que com muita presteza forneceu os animais para que fosse realizado o experimento, a sua contribuição foi de real e extrema importância para a elaboração deste estudo. A professora Ângela Patrícia por colocar a disposição o laboratório e os equipamentos para realização das análises.

Ao Frigorífico LM por fornecer tão gentilmente o espaço e funcionários para a realização do abate dos animais e as avaliações na carcaça. 
O meu muito obrigada a todos, que de alguma forma, contribuíram para chegar a conclusão deste tão desejado trabalho.

“A coisa mais indispensável a um homem é reconhecer o uso que deve fazer do seu próprio conhecimento" Platão. 


\section{INDICE}

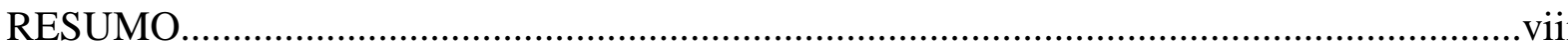

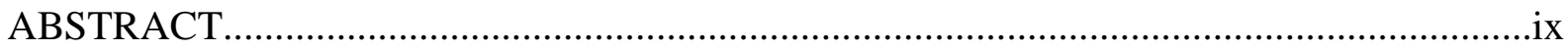

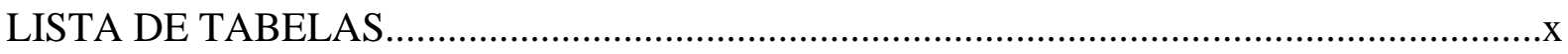

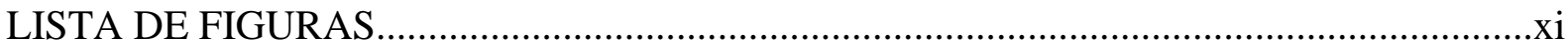

CAPITULO 1

1. INTRODUÇÃO

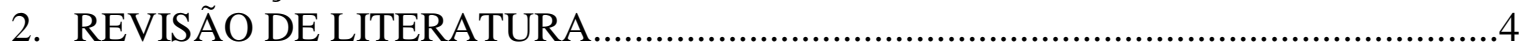

2.1 Histórico da ovinocultura no Brasil e no Distrito Federal.......................................4

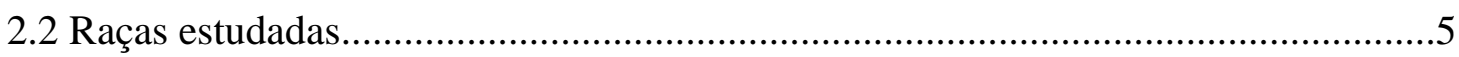

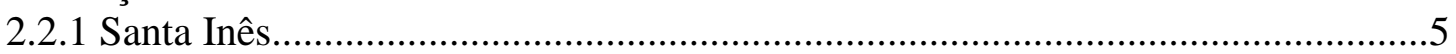

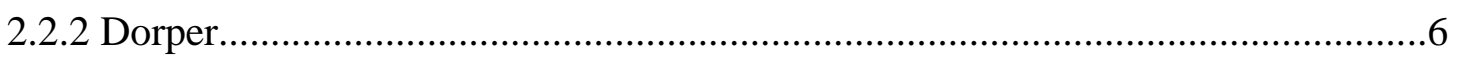

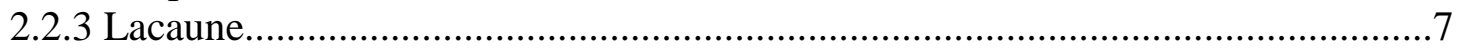

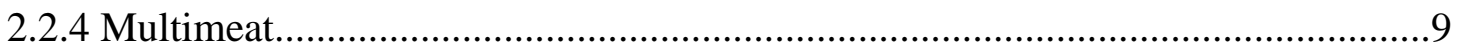

2.3 Uso de cruzamento industrial nos sistemas de produção de ovinos.........................9

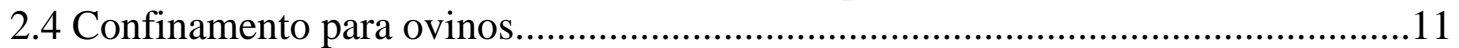

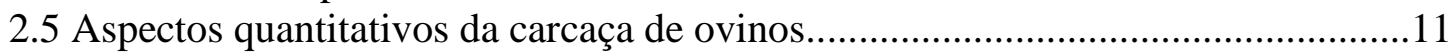

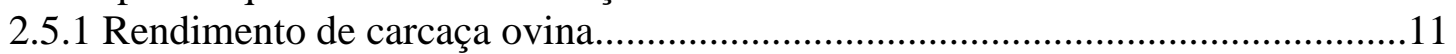

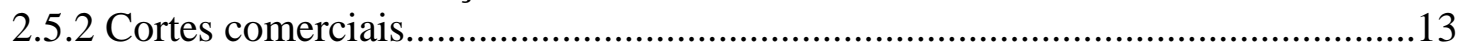

2.5.3 Perda de peso no resfriamento da carcaça......................................................14

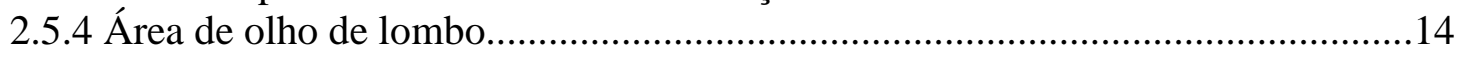

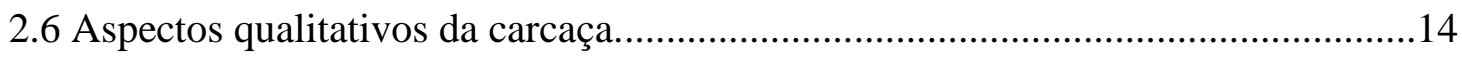

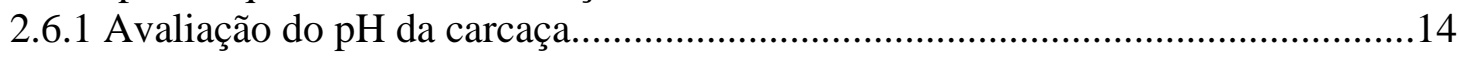

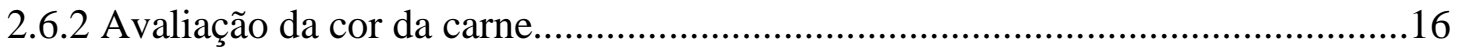

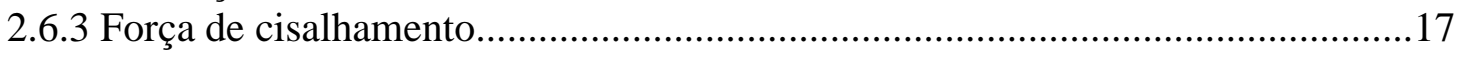

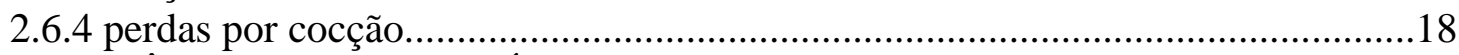

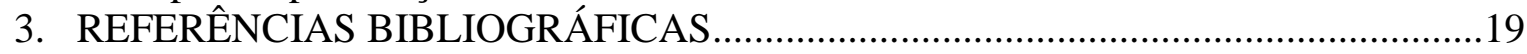

CAPÍTULO 2 - DESEMPENHO E CARACTERÍSTICAS QUANTITATIVAS DA CARCAÇA DE CORDEIROS DE DIFERENTES GRUPOS

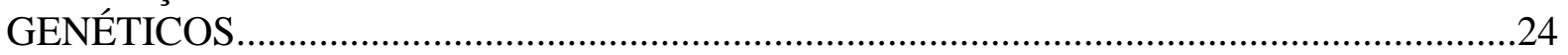

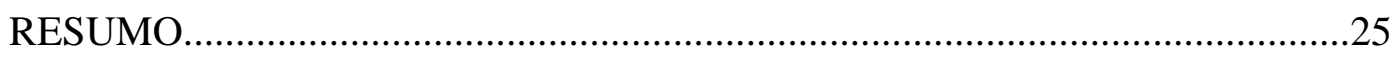

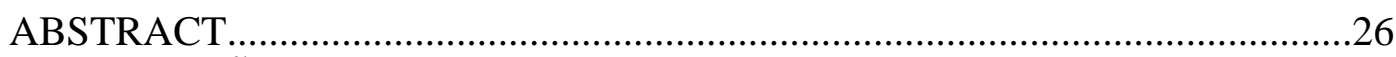

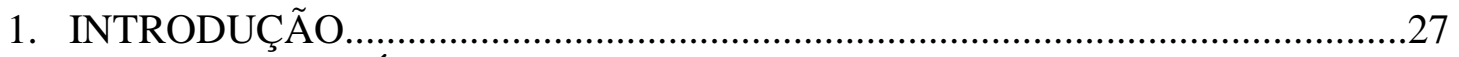

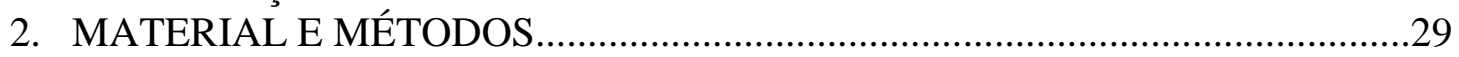

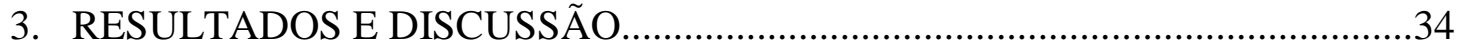

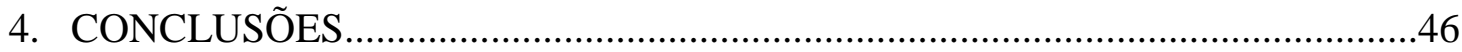

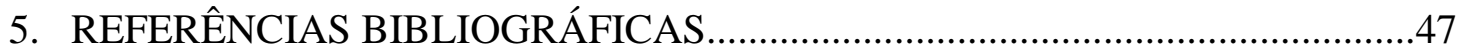

CAPÍTULO 3 - CARACTERÍSTIVAS QUALITATIVOS DA CARCAÇA E DA CARNE DE CORDEIROS DE DIFERENTES GRUPOS GENÉTICOS

RESUMO

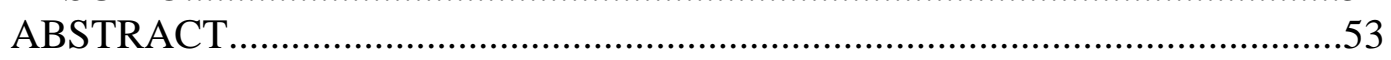

1. INTRODUÇÃO

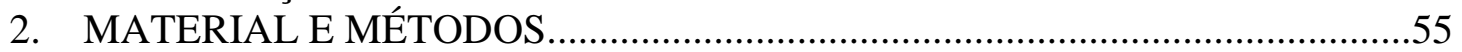

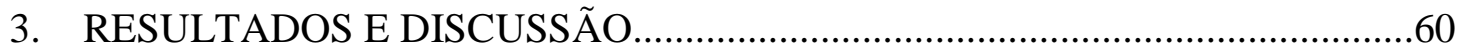

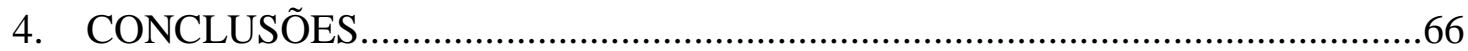

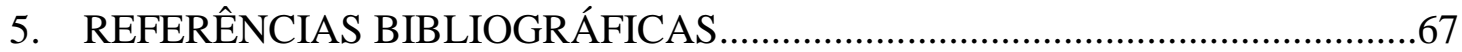




\title{
RESUMO \\ DESEMPENHO E CARACTERÍSTICAS DA CARCAÇA E DA CARNE DE CORDEIROS DE DIFERENTES GRUPOS GENÉTIOS
}

\author{
Luana Frossard Gomes de Aguiar ${ }^{1}$, Clayton Quirino Mendes ${ }^{1}$ \\ ${ }^{1}$ Faculdade de Agronomia e Medicina Veterinária - UnB, DF.
}

Objetivou-se com a presente pesquisa avaliar o desempenho, as características quantitativas e qualitativas da carcaça e a qualidade da carne de cordeiros de três diferentes grupos genéticos terminados em sistema de confinamento. Utilizou-se 24 cordeiros, machos, não castrados, de diferentes grupos genéticos formados pelo cruzamento das raças Santa Inês (SI) x White Dorper (WD), SI x Lacaune, SI x Multimeat. Os animais foram distribuídos em delineamento inteiramente casualizado em arranjo fatorial 3 X 2 (3 grupos genéticos e 2 tipos de parto), foram confinados em baias individuais.e alimentados com ração composta de silagem de milho e concentrado (25:75). Os animais foram abatidos ao atingirem o peso corporal médio de 39,26 kg, obtendo-se o peso da carcaça quente (PCQ). Após uma hora da realização do abate, as carcaças foram colocadas em câmara fria a $5{ }^{\circ} \mathrm{C}$ e mantidas por 24 horas, obtendo-se $o$ peso de carcaça fria (PCF). Foram determinados o rendimento de carcaça quente (RCQ\% = $\left.\mathrm{PCQ}^{*} 100 / \mathrm{PJ}\right)$ e o rendimento da carcaça fria $(\mathrm{RCF} \%=\mathrm{PCF} * 100 / \mathrm{PJ})$. Após o período de resfriamento, as carcaças foram seccionadas longitudinalmente e a metade esquerda dividida em cinco cortes comerciais: pescoço, paleta, costela, lombo e perna. No músculo Longissimus dorsi determinou-se o $\mathrm{pH}$ e a temperatura das carcaças. $\mathrm{O} \mathrm{pH}$ e a temperatura foram determinados novamente após o período de resfriamento. Determinou-se área de olho de lombo (AOL) e espessura de gordura subcutânea (EG) no músculo Longissimus dorsi. Para as análises qualitativas foram retiradas porções do músculo Longissimus dorsi de cada carcaça esquerda, determinando-se, a cor: luminosidade $\left(\mathrm{L}^{*}\right)$, intensidade de vermelho $\left(\mathrm{a}^{*}\right)$ e amarelo (b*); as perdas por cocção (PPC) e a força de cisalhamento (FC). Entre os grupos genéticos, observou-se que os animais do cruzamento SI x Multimeat apresentaram maior consumo de matéria seca em relação ao peso vivo. Houve diferença entre o tipo de parto, sendo obsevados valores superiores para as variáveis peso corporal inicial e final, consumo de matéria seca e eficiência alimentar nos animais nascidos de parto simples, além de apresentarem maior área de olho de lombo e maior peso da paleta, lombo, perna e cortes nobres. Em relação aos parâmetros qualitativos da carcaça e de qualidade da carne, observou-se maior luminosidade (L*) nas amostras provenientes dos animais do cruzamento SI x Multimeat e maior intensidade de vermelho ( $\left.b^{*}\right)$ nas amostras de animais provenientes de parto simples. As raças paternas utilizadas (White Dorper, Lacaune ou Multimeat) podem ser utilizadas no cruzamento com a raça Santa Inês em programas de cruzamento industrial na ovinocultura de corte visando aumentar a eficiência na produção de carne.

Palavres-chave: confinamento, cruzamento, lacaune, multimeat, ovinos 


\title{
ABSTRACT \\ PERFORMANCE AND CHARACTERISTICS OF CARCASS AND MEAT OF LAMBS FROM DIFFERENT GENETIC GROUPS
}

\author{
Luana Frossard Gomes de Aguiar ${ }^{1}$, Clayton Quirino Mendes ${ }^{1}$ \\ ${ }^{1}$ Faculdade de Agronomia e Medicina Veterinária - UnB, DF.
}

This research aimed to evaluate the performance, quantitative and qualitative characteristics of the carcass and meat quality of lambs of three different genetic groups finished in feedlot system. We used 24 lambs, male, uncastrated, of different genetic groups formed by the intersection of Santa Inês (SI) x White Dorper (WD), SI x Lacaune, SI x Multimeat. The animals were distributed in a completely randomized design in a factorial arrangement $3 \times 2$ ( 3 genetic groups and two types of parturition) were confined in individuais pens and fed with feed consisting of corn silage and concentrate (25:75). The animals were slaughtered when they reached the average body weight of $39.26 \mathrm{~kg}$, resulting in the hot carcass weight (HCW). After one hour of completion of the slaughter, the carcasses were placed in a cold chamber at $5^{\circ} \mathrm{C}$ and maintained for 24 hours, obtaining the cold carcass weight (CCW). Were determined the hot carcass yield (WHR\% $=$ PCQ $* 100 /$ PJ) and the yield of the cold carcass $(\mathrm{RCF} \%=\mathrm{PCF} * 100 / \mathrm{PJ})$. After the cooling period, the carcasses were split lengthwise and the left half divided into five commercial cuts: neck, shoulder, rib, loin and leg. Longissimus dorsi muscle was determined the $\mathrm{pH}$ and temperature of the carcasses. Then the carcasses were subjected to cooling in cold storage for 24 hours at $5{ }^{\circ} \mathrm{C}$ and then the $\mathrm{pH}$ and the temperature were determined again. It was determined ribeye area (REA) and fat thickness (EG) in Longissimus dorsi. For qualitative analysis of the muscle were removed portions of Longissimus dorsi for each left housing determining the color: lightness ( $\left.\mathrm{L}^{*}\right)$, redness $\left(\mathrm{a}^{*}\right)$ and yellow (b*); the cooking losses (PPC) and shear force (SF). Among genetic groups, it was observed that the animals for SI x Multimeat crossing had higher dry matter intake relative to body weight. There was a difference between the type of parturition, and observed higher values for the variables initial and final body weight, dry matter intake and feed efficiency in animals born of simple birth, besides presenting larger loin eye area and greater weight palette, loin, leg and prime cuts. Regarding the qualitative parameters of the carcass and meat quality, there was a higher brightness $\left(\mathrm{L}^{*}\right)$ in samples from the animals crossing SI $\mathrm{x}$ Multimeat and more intense red $\left(b^{*}\right)$ in animal samples from simple birth. The races fathers used (White Dorper, Lacaune or Multimeat) can be used at the intersection with Santa Ines in crossbreeding programs on the cutting sheep industry to increase efficiency in meat production.

Keywords: crossing, feedlot, lacaube, multimeat, sheep 


\section{LISTA DE TABELAS}

Tabela 2.1 Composição bromatológica da dieta fornecida aos animais .30

Tabela 2.2 Média dos valores de PI, PF, GF, GMD, CMS, CA e EA.....................................34

Tabela 2.3 Média dos valores de PCQ, PCF, RCQ, RCF, PRR, ICC .....................................36

Tabela 2.4 Área de olho de lombo e espessura de gordura................................................40

Tabela 2.5 Pesos médios e porcentagens dos cortes comerciais............................................42

Tabela 3.1 Valores de $\mathrm{pH}$ e temperatura final após o abate.................................................60

Tabela 3.2 Valores de força de cisalhamento, perdas por cocção, luminosidade (L*), intensidade de vermelho $\left(\mathrm{a}^{*}\right)$ e intensidade de amarelo

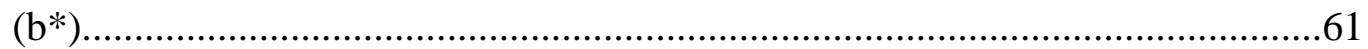

Tabela 3.3 Porcentagem dos tecidos constituintes da perna................................................63 


\section{LISTA DE FIGURAS}

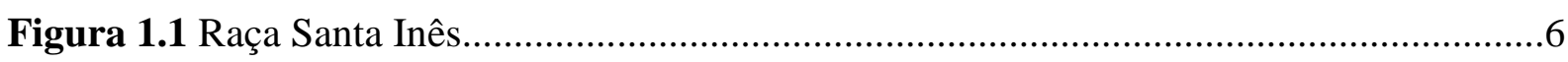

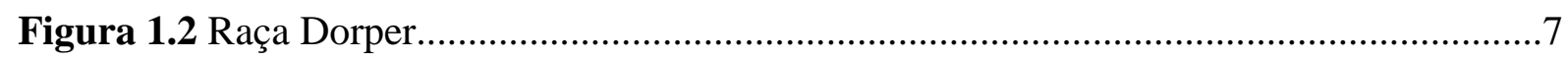

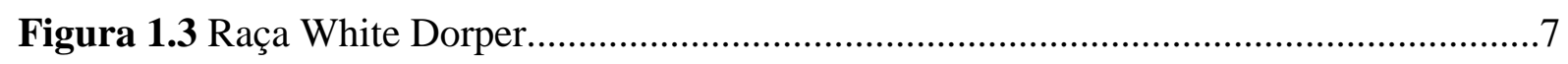

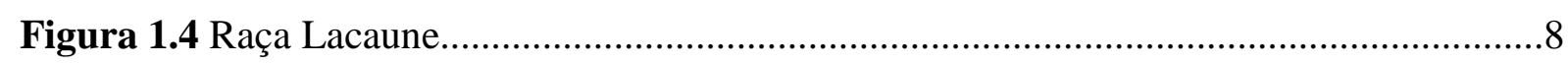

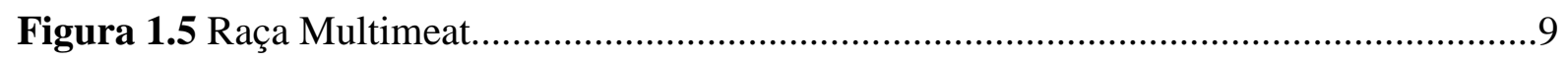

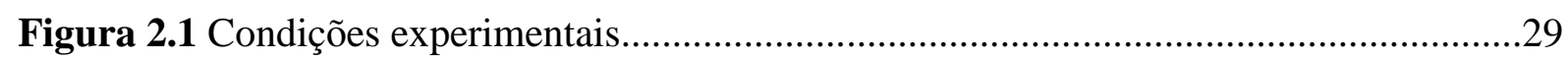

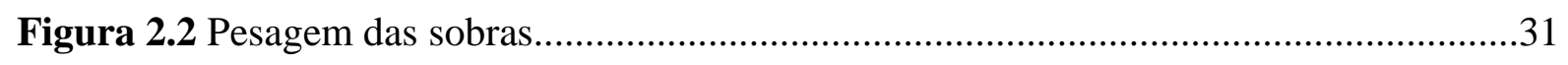

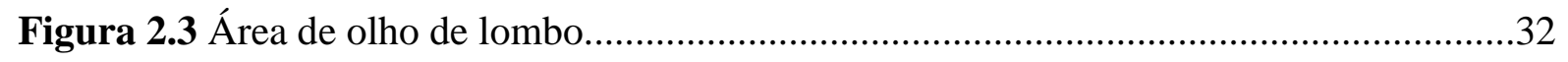

Figura 2.4 Medida da espessura de gordura subcutânea (EG).............................................32

Figura 2.5 Metade esquerda da carcaça dividida em 5 cortes comerciais: perna, lombo, costelas, paleta e pescoço............................................................................... 33

Figura 3.1 Mensuração do pH e temperatura no músculo Longissimus dorsi utilizando termômetro com eletrodo................................................................................56

Figura 3.2 Avaliação da cor no músculo Longissimus dorsi utilizando colorímetro Minolta

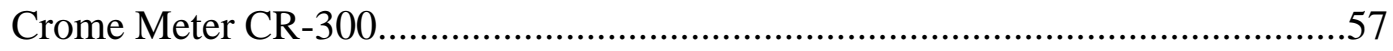

Figura 3.3 Bifes de $2,5 \mathrm{~cm}$ de espessura em forno pré-aquecido, monitorado com

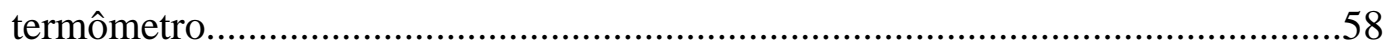

Figura 3.4 Cilindros para avaliação da maciez da carne e aparelho para avaliação da força de

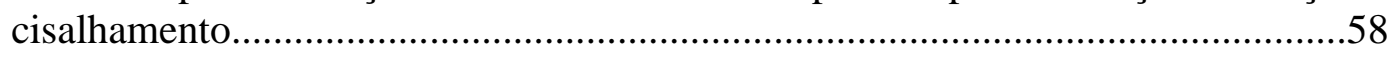


CAPITUlO 1 


\section{INTRODUÇÃO}

A ovinocultura vem se destacando cada dia mais no Brasil, devido ao rápido giro de capital proporcionado pela atividade, melhor aproveitamento da área de pastagem e também pela sua rápida reprodução, com possibilidade de se obter média de 1,5 crias por ano.

$\mathrm{O}$ mercado consumidor dos grandes centros urbanos possui maior aceitabilidade por carne de ovinos produzida a partir de animais jovens (cordeiros), apresentando idade em torno de 6 a 8 meses e com peso vivo de 30 a $35 \mathrm{~kg}$. Desta forma, na produção de cordeiros para abate, o manejo alimentar deve permitir rápida terminação dos animais, favorecendo dessa forma, a obtenção de carcaças com características adequadas para satisfazer os consumidores que buscam produtos mais saborosos e saudáveis. Diante desse contexto, o sistema de criação em confinamento é uma importante alternativa para o incremento na oferta regular de um produto de boa qualidade. Além disso, o confinamento possibilita alto giro de capital, padronização das carcaças e dos cortes cárneos, aumento da produtividade, aumento da renda do produtor, redução da idade ao abate e liberação das pastagens para criação das demais categorias, assim como para a agricultura (Almeida, 2004).

Segundo Carneiro et al. (2007), o cruzamento entre raças tem sido muito utilizado com o objetivo de aumentar a capacidade produtiva dos rebanhos ovinos e, consequentemente, favorecendo a conjugação de características desejáveis de cada raça e a exploração da heterose. Adicionalmente, Silva Sobrinho (2001) destacou que o cruzamento industrial é uma excelente ferramenta para os sistemas de produção de ovinos de corte, uma vez que os animais puros possuem preços elevados e os animais considerados sem raça definida apresentam baixo rendimento de carcaça. É possível obter produtos com maior velocidade de crescimento, melhor conformação e composição da carcaça. A eficiência deste processo depende das raças selecionadas, da individualidade dos animais e do nível nutricional dos mesmos.

Diante desse contexto, objetiva-se com o presente estudo avaliar o desempenho produtivo, assim como as características quantitativas e qualitativas da carcaça e a qualidade 
da carne de cordeiros de diferentes grupos genéticos (Santa Inês x White Dorper; Santa Inês x Lacaune; Santa Inês x Multimeat) terminados em sistema de confinamento. 


\section{REVISÃO DE LITERATURA}

\subsection{Histórico da ovinocultura no Brasil e no Distrito Federal}

No Brasil, a ovinocultura é uma atividade típica das regiões Nordeste e Sul, sendo que na região Nordeste a atividade é desenvolvida principalmente, em pequenas propriedades e criações direcionadas para subsistência (Barbosa, 2005). O mercado consumidor de carne ovina no Brasil encontra-se em desenvolvimento, mas ainda é caracterizado por diferenças regionais. Os maiores mercados consumidores concentram-se no entorno das regiões produtoras, entretanto, a demanda tem se expandido em outras regiões como Centro-Oeste e Sudeste.

Em 2010, o Brasil apresentou o décimo sétimo maior rebanho ovino do mundo com aproximadamente 17,3 milhões de cabeças, representando apenas 1,61\% do rebanho total mundial (FAO, 2013). Esses dados indicam grandes oportunidades para o fortalecimento da cadeia produtiva e crescimento desta atividade. O rebanho ovino brasileiro tem apresentado crescimento pouco acelerado, porém constante, desde o ano de 2002. Enquanto o rebanho mundial cresceu apenas $1,04 \%$ entre os anos de 2004 e 2010, o rebanho brasileiro cresceu 15,43\% no período, passando de 15 milhões de animais (IBGE, 2013). Dados da FAO (2013) indicam que no Brasil no ano de 2010 foram abatidos 5 milhões de ovinos com um rendimento de mais de 80 mil toneladas de carne. Estudos realizados pelo IBGE (2011) demonstraram valores da evolução do rebanho ovino na região do Distrito Federal, mostrando valores de 20.416 cabeças no ano de 2010.

De acordo com Simplício (2001), o Brasil tem todos os atributos necessários para, além de atender o mercado consumidor interno de carne ovina, ser também um grande exportador, pois atualmente cerca de $40 \%$ da carne ovina consumida oficialmente no país é importada do Uruguai, Argentina e Nova Zelândia. Porém, o volume importado é decrescente desde o ano de 2009, quando houve redução de $12,66 \%$ na importação deste produto. No mês de dezembro de 2011, o Brasil importou 40,2\% menos carne ovina uruguaia, comparada a 
novembro do mesmo ano, totalizando 695 toneladas e queda de 60,4\%, quando comparado ao mesmo mês do ano anterior (FAO, 2013).

Fatores como hábito alimentar e poder aquisitivo exercem grande influência sobre o consumo, mas o baixo consumo no país pode estar relacionado, principalmente, à qualidade do produto colocado à venda, em que comumente se encontram no mercado carcaças de baixa qualidade e principalmente provenientes de animais mais velhos, esses fatores esses que influenciam diretamente e negativamente no consumo (Almeida Júnior et al., 2004).

Alguns estudos realizados acerca do mercado consumidor de carne ovina no Centro-Oeste, demonstram crescimento do mercado da ovinocultura no Distrito Federal, identificando o perfil predominante de consumidores da classe A e B e que utilizavam os produtos tanto em casa como em restaurantes, ou compravam a carne em supermercados para consumo doméstico (Souza, 2006).

\subsection{Opções de raças para o cruzamento industrial}

\subsubsection{Santa Inês}

A raça Santa Inês é nativa do Nordeste brasileiro, oriunda do estado da Bahia, originada do cruzamento de ovinos Bergamácia (lanada) com Morada Nova e Crioulas (deslanadas), seguida de um período de seleção para ausência de lã, com o objetivo de produção de carne (Figueiredo et al., 1989). No final dos anos 1980, um pequeno número de criadores adicionou sangue Sulfolk, observado pela morfologia externa dos animais Santa Inês (Sousa, 2008).

São os ovinos deslanados de maior expansão, a raça mais difundida e estudada no Brasil Tropical, encontrada em todo o Nordeste, bem como em vários estados do Sudeste, Centro-Oeste e Norte do país. São caracterizados pelo grande porte, mochos, de pelagem vermelha, preta, branca e suas combinações e média de peso corporal dos machos adultos de 80 a $100 \mathrm{~kg}$ e, para fêmeas, de 50 a $70 \mathrm{~kg}$. As aptidões incluem carne e pele; as fêmeas são precoces, apresentando bons índices reprodutivos e boa produção de leite, o que destaca a raça como excelente alternativa à produção de carne para quase todas as regiões tropicais do Brasil (Silva Sobrinho, 2001). 


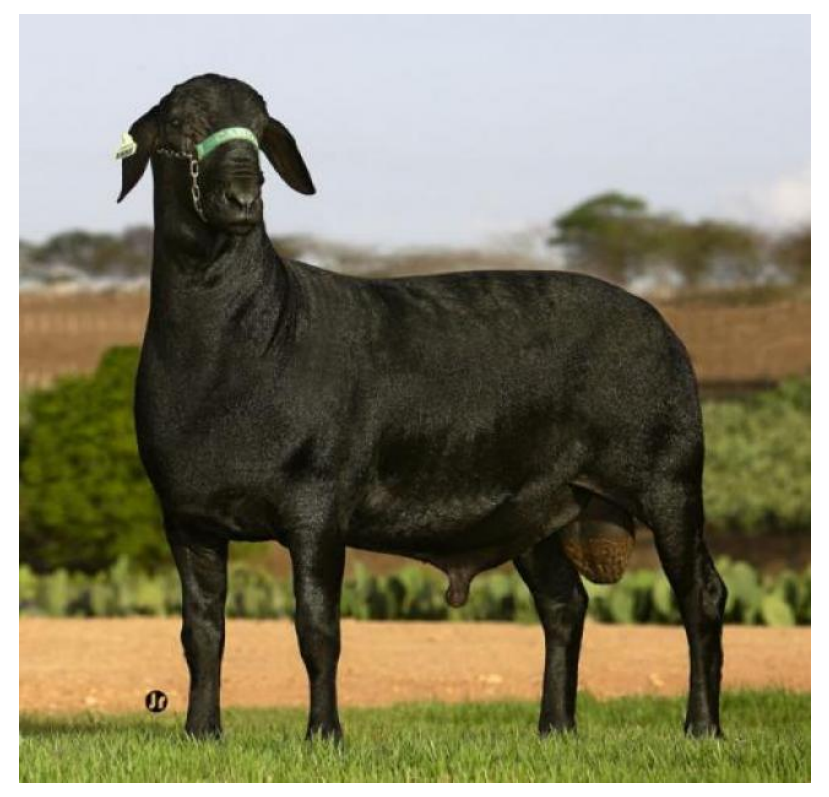

Figura 1.1- Raça Santa Inês

Fonte: www.absantaines.com.br

A raça Santa Inês tem demonstrado ser uma excelente alternativa para incrementar a produção de carne ovina nas regiões de clima tropical. No entanto, as características de carcaça são inferiores às das raças lanadas ou semilanadas de clima temperado especializadas para corte e/ou de seus mestiços, além de ser mais tardia quanto à deposição de gordura de cobertura, fator que, entretanto, não a compromete como opção viável à oferta de carne sendo então utilizada em cruzamentos industriais (Furusho-Garcia, 2004).

\subsubsection{Raça Dorper}

A raça Dorper foi introduzida no Nordeste do Brasil, no final dos anos 90, com o objetivo de usar este novo genótipo, especializado na produção de carne, em cruzamentos com ovelhas de outras raças devido à sua adaptabilidade, habilidade materna, altas taxas de crescimento e musculosidade, gerando carcaças de qualidade (Rosanova et al., 2005). Apesar do porte médio, essa raça tem alta velocidade de ganho de peso, reduzindo o tempo para o abate o que leva à produção de carne mais macia, seu rendimento de carcaça é superior a $50 \%$, sendo animais que se adaptam bem a diferentes ambientes e tipos de criação (Braga, 2011).

A raça, de origem sul-africana foi desenvolvida com um único propósito: produção de carne sobre variadas condições ambientais. Originária de cruzamentos entre as 
raças Dorset Horn (pelagem branca) e Blackhead Persian (Somalis), produziu desde 1930, os primeiros ovinos resultantes desse cruzamento; alguns eram totalmente brancos, recebendo o nome de Dorsian. No Brasil, os ovinos resultantes desse cruzamento, apresentavam o corpo branco e o pescoço preto, pertencem à raça Dorper (Figura 1.2) e os animais com pelagem totalmente branca são da raça White Dorper (Figura 1.3).

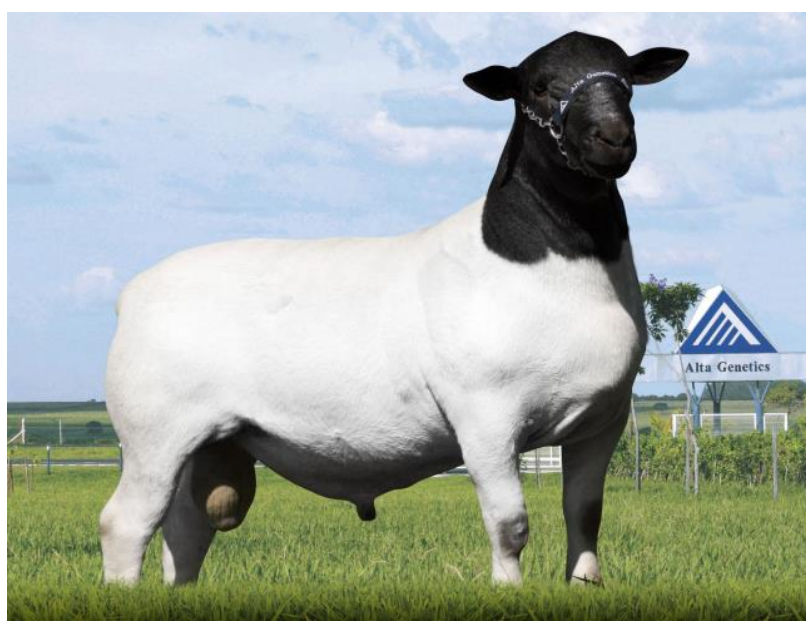

Figura 1.2: Raça Dorper Fonte: www.altagenetics.com.br

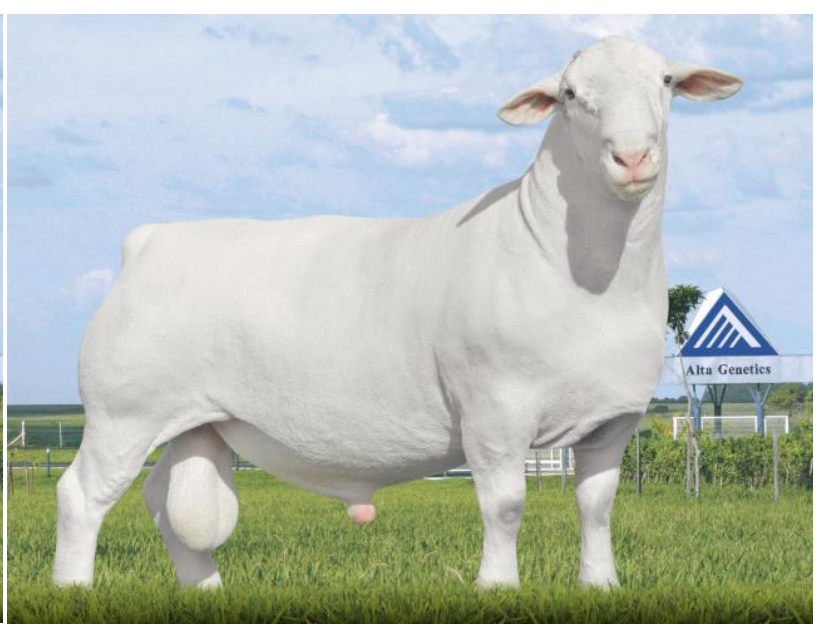

Figura 1.3: Raça White Dorper Fonte: www.altagenetics.com.br

Partos múltiplos são comuns para essa raça, aliados à grande produção de leite, caracterizando-as matrizes como fêmeas de boa habilidade materna. São animais de porte médio, compactos e musculosos.

Os animais pertencentes à essa raça apresentam alta velocidade de ganho de peso, boa conformação e rendimento de carcaça, o que permite a utilização destes animais como raça paterna, principalmente para cruzamentos com fêmeas Santa Inês, pois seus descendentes, além de apresentarem bom desempenho produtivo, preservam nas fêmeas características reprodutivas de ambas as raças, com longo período de cio e boa habilidade materna (Silva Sobrinho, 2001).

\subsubsection{Raça Lacaune}

Raça francesa, originária dos Montes Lacaune,. Tem como origem os diversos grupos ovinos que existiam nos departamentos de L’Aveyron. O berço da raça situa-se na região produtora de leite destinado à fabricação do queijo Roquefort (Caprileite ACCOMIG). 


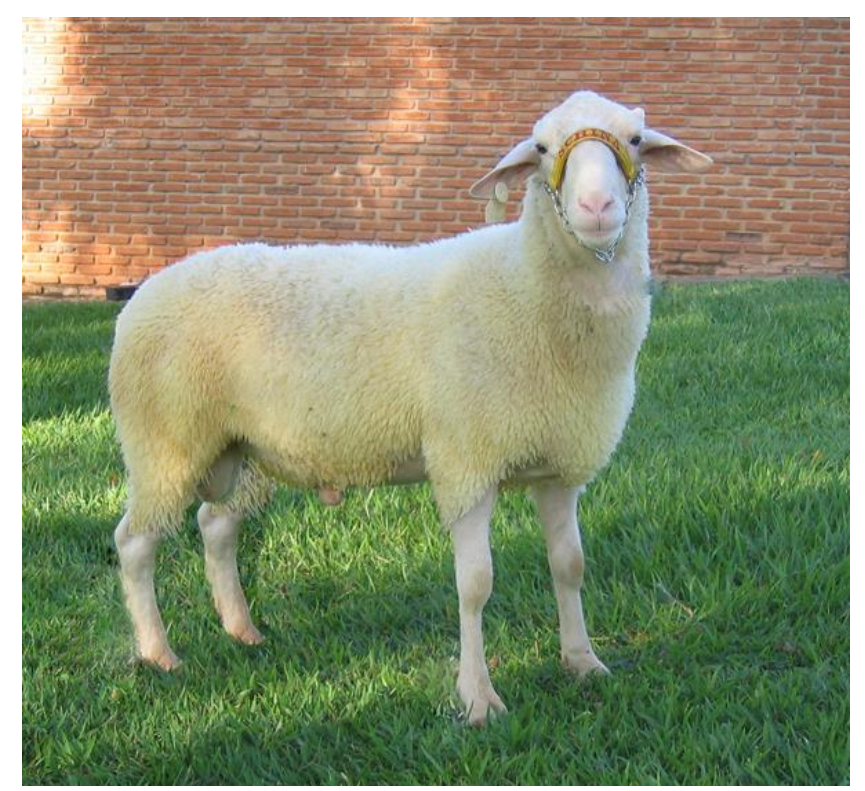

Figura 1.4 - Raça Lacaune

Fonte: www.arcoovinos.com.br

A seleção da raça teve origem a partir de 1870, mas somente em 1886 foi instalada a primeira indústria de queijo da Sociedade de Roquefort, localidade de Lacaune. Em 1928, foi organizado o sindicato de criadores que tem a seu cargo o registro genealógico e o controle leiteiro dos ovinos Lacaune (Vieira, 1967).

A raça Lacaune é considerada leiteira, mas existe uma linha para produção de carne, é a raça mais criada na França e em expansão na Espanha, sendo oficialmente considerada como raça da União Européia. É um animal com boa rusticidade e instinto materno, longa atividade sexual e prolificidade de média a alta, além de carne de boa qualidade (Sañudo, 2008).

Os primeiros ovinos com aptidão leiteira da raça Lacaune foram trazidos para o Brasil em 1992, adaptando-se bem às condições climáticas e de alimentação do sul do Brasil (Brito, 2004). Com a expansão da exploração do leite ovino destinado à produção de queijos finos, a raça Lacaune vem difundindo rapidamente entre os criadores brasileiros e constata-se a ausência de informações científicas na literatura sobre o crescimento e desempenho produtivo de cordeiros mestiços Lacaune x Santa Inês. Uma vez que a raça Santa Inês compõe a base do rebanho nacional, o cruzamento "absorvente" entre as duas raças pode ser uma ferramenta para obtenção de animais Puro por Cruza (PC), além de promover melhorias na produção de leite nas matrizes Santa Inês e, consequentemente, disponibilizar cordeiros com maior peso ao desmame e melhor desempenho e características de carcaça (Sañudo, 2008). 


\subsubsection{Raça Multimeat}

Raça composta, oriunda de cruzamento entre vários grupos genéticos, sendo baseada principalmente na raça White Suffolk, o Multimeat se diferencia por conter o gene denominado Booroola, que é responsável por um controle na taxa de ovulação e por aumentar em $60 \%$ a taxa de nascimentos, possibilitando maior velocidade da evolução dos rebanhos ovinos, maior produtividade e maior qualidade dos animais nascidos, além de possibilitar o aumento de renda em rebanhos menores (Multimeat, 2008).

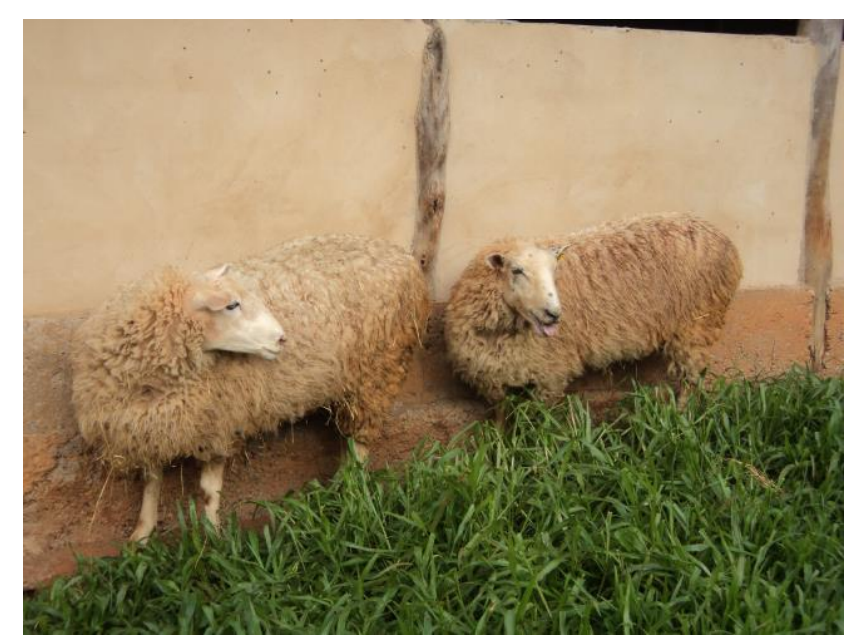

Figura 1.5 - Raça Multimeat

Fonte: Rafael Lima Macedo

Francis (2008) relatou que ovelhas que tiveram parto simples, duplo, triplo e quádruplo desmamaram 63,112, 135 e $172 \mathrm{~kg}$ de cordeiro, respectivamente. No entanto, o autor destacou ainda que o objetivo da inserção deste gene aos cruzamentos é produzir carcaças pesadas (18 a $20 \mathrm{~kg}$ ) e evitar multiplicar cordeiros mal terminados. Isto requer a concepção do sistema como um todo, com especial atenção ao momento do parto e no tempo para o desmame.

$\mathrm{O}$ autor supracitado ressaltou que, em estudo realizado por alguns pesquisadores, a conversão alimentar de cordeiros que possuem este gene foi $46 \%$ mais eficiente para as ovelhas que criaram gêmeos quando comparadas aquelas que criaram somente um borrego.

\subsection{Uso de cruzamento industrial nos sistemas de produção de ovinos}

Os cruzamentos industriais constituem um sistema de comprovada eficiência em países produtores de carne ovina, tendo como base três processos biológicos principais: 
eficiência reprodutiva da raça utilizada, velocidade de crescimento e nível de nutrição disponível (Figueiró, 1979). Os cruzamentos industriais são utilizados, entre outras razões, para se obter carcaça com melhor conformação e, consequentemente, com melhor qualidade (Sidwell \& Miller, 1971).

O cruzamento de uma raça de baixo potencial para a produção de carne com raças especializadas para este propósito é uma alternativa interessante para melhorar parâmetros como rendimento de carcaça e obter cortes com adequada proporção de músculo, osso e gordura (Figueiró, 1979). Aumentar a capacidade produtiva do rebanho ovino vem-se tornando uma prioridade no Brasil. Neste sentido, o cruzamento industrial é uma prática desejável, por favorecer a conjugação das características desejáveis de cada raça, e pelo fato das crias apresentarem maior vigor híbrido na primeira geração, expressando um desempenho superior ao observado para a média de seus pais (Notter, 2000).

Para Caderlino (1989), o cruzamento entre raças ovinas pode propiciar maior velocidade de crescimento, conformação e melhor qualidade da carcaça e da carne. Portanto, a utilização de cruzamentos constitui uma forma de aperfeiçoar o crescimento e a qualidade do produto final e, consequentemente, a economia da cadeia produtiva.

Existem vários tipos de cruzamento e cada tipo deve ser utilizado de acordo com o objetivo de criação. Se o produtor deseja vender boa parte dos seus animais provenientes do cruzamento de duas raças, o cruzamento mais indicado é simples ou industrial. Neste tipo de cruzamento todos os animais $1 / 2$ sangue originados do acasalamento das duas raças escolhidas, serão destinados para o abate, independente do sexo da cria, porém alguns criadores reservam as borregas F1 para a reposição ou ampliação do rebanho (Machado et al., 1999).

Através de cruzamentos com raças lanadas, especializadas na produção de carne, é possível melhorar as características de carcaça de ovinos Santa Inês, principalmente em algumas regiões do país, onde as condições de manejo e nutrição são melhores (Sousa et al., 2003).

Cordeiros provenientes do cruzamento industrial apresentam maior peso ao nascimento (500 a $800 \mathrm{~g}$ superior aos cordeiros de raças europeias) e com maior viabilidade ao nascimento (Lasley, 1978). De acordo com Madruga et al. (2006), a utilização de raças de cordeiros de corte em sistemas de cruzamentos, como a raça Santa Inês, tem como objetivo melhorar as características de carcaça, possibilitando a geração de produtos com maior potencial genético, diminuindo o tempo de abate e os custos de produção. 


\subsection{Confinamento para ovinos}

O confinamento tem despertado interesse de muitos criadores como alternativa para melhorar o sistema de produção, visando manter a regularidade na oferta de carne e peles durante o ano para atender o mercado nacional (Medeiros, 2006).

A terminação de cordeiros em confinamento apresenta uma série de benefícios, como menor mortalidade dos animais, devido a menor incidência de verminose e maior controle de possíveis doenças, bem como melhor controle nutricional; o que proporciona abate precoce dos animais e com carcaças de alta qualidade, refletindo em melhor preço pago pelo consumidor (Oliveira et al., 2002). O sistema de produção intensiva (confinamento) também permite oferecer ao mercado consumidor um produto padronizado e de superior qualidade. Além do manejo alimentar, a associação dos genótipos de maior potencial de produção de carne, é de extrema importância para o sucesso do sistema de produção.

O sistema de terminação de cordeiros em confinamento apresenta impactos sobre o sistema de produção como um todo, sobretudo, no aumento na escala de produção, devido à liberação de áreas de pastagens para o rebanho de cria, e o melhor retorno sobre o capital investido, especialmente a terra, em função dos incrementos em produtividade (Madruga et al., 2006).

As maiores desvantagens do confinamento se encontram nos altos custos de produção, principalmente na alimentação, que constitui um fator determinante no aspecto financeiro (Oliveira et al., 2002). Para que o confinamento seja uma opção economicamente viável, é necessário que se utilize uma dieta de baixo custo que proporcione alto ganho de peso médio diário, baixa conversão alimentar, reduzido período da terminação e uma margem atrativa de lucro (Madruga et al., 2006).

\subsection{Aspectos quantitativos da carcaça de ovinos}

\subsubsection{Rendimento de carcaça ovina}

Segundo Medeiros et al. (2005) o foco da cadeia produtiva que antes era o produtor, passou a ser o consumidor final, que este está cada vez mais exigente e valoriza os produtos consumidos pelo grau de satisfação que estes lhe proporcionam. Aplicando para carcaça, a qualidade poderia ser definida como o conjunto de características, cuja importância relativa lhe confere maior aceitação e um maior preço frente aos consumidores e a demanda 
do mercado. Sañudo (1991) definiu a qualidade de maneira ampla e objetiva como a adequação do produto ao uso e exigências particulares que se lhe façam.

$\mathrm{O}$ rendimento de carcaça está diretamente relacionado ao valor comercial de cordeiros, pois geralmente é um dos primeiros índices a ser considerado, por expressar a relação percentual entre o peso da carcaça e o peso vivo do animal. O rendimento de carcaça em ovinos varia de 45 a 50\%, podendo ser influenciado por fatores como raça, sistema de alimentação, peso e idade do animal. De acordo com Pérez (1995), o rendimento de carcaça é determinante do maior ou menor custo da carne para o consumidor, tornando-se relevante para os criadores que investem nessa atividade. Os rendimentos de carcaça, dentre outros fatores, constituem importantes parâmetros na determinação dos índices de rentabilidade dos diversos segmentos envolvidos na cadeia produtiva da carne ovina.

A partir dos pesos da carcaça quente e fria, são calculados os rendimentos. Quando se utiliza o peso da carcaça quente para calcular o rendimento, ocorre uma diferença de 2 a $3 \%$ em virtude da variação entre os pesos da carcaça fria (24 horas de refrigeração) e quente (após o abate). Estas diferenças são perdas de peso ao resfriamento, que dependem da quantidade de gordura de cobertura, responsável pela proteção da carcaça e diminuição das perdas de umidade. Como é comercializada a carcaça fria, o rendimento considerado é chamado comercial (Garcia, 1998).

Segundo Martinez et al. (2001), os maiores rendimentos de carcaça podem estar associados à baixa porcentagem de componentes não constituintes da carcaça e/ou à maior deposição de tecido adiposo nos animais suplementados, bem como à semelhança no peso do conteúdo gastrointestinal. Os fatores idade e peso devem ser considerados quando se busca uniformização e comercialização justa de um produto de qualidade e consequentemente de maior aceitação pelo consumidor (Osório et al., 1999).

Nesse sentido, o aumento do peso corporal pode determinar alterações nas características de carcaça e interesse comercial, como aumento no peso e rendimento de carcaça, na área de olho de lombo e na sua quantidade de gordura, melhora a conformação da carcaça e maior deposição de tecido por unidade de comprimento da carcaça (Motta et al., 2001). Zund et al. (2003) verificaram maior cobertura de gordura na carcaça quando houve elevação do peso corporal ao abate, o que proporcionou carcaças com mais tecido adiposo. Rodrigues et al. (2006) ressaltaram que a gordura é um elemento importante de proteção na carcaça, principalmente na câmara fria, protegendo-a dos efeitos negativos da baixa temperatura, o congelamento e a perda excessiva de água pela formação de cristais de gelo dentro das células. 
Bueno et al. (2000) ao avaliarem as características de carcaça de ovinos abatidos em diferentes idades e utilizando diferentes fontes de proteína na dieta e verificaram aumento linear para peso de carcaça quente e fria, assim como seus cortes e componentes, o que denota acréscimos de tecidos nas carcaças com o aumento do peso corporal dos animais.

\subsubsection{Cortes comerciais}

Os cortes na carcaça em peças individualizadas associados à apresentação do produto são importantes fatores na comercialização. Os tipos de cortes, que variam de acordo com a região, além de agregarem valor, permitem preços diferenciados entre diversas partes da carcaça e evita desperdícios da mesma (Silva Sobrinho \& Silva, 2000). A proporção destes cortes na carcaça é um importante índice de avaliação de qualidade, pois o conhecimento dos pesos e rendimentos dos principais cortes permite uma interpretação mais minuciosa do desempenho animal.

O rendimento dos cortes sofre influência direta do peso e sexo do animal, tendo como base o estado nutricional (Santos, 2002). A idade é outro fator determinante no desenvolvimento do animal e, consequentemente, dos cortes da carcaça (Santos, 2003), bem como a raça, sendo que a proporção dos cortes difere em função dos diferentes estágios de maturidade de cada raça. Assim sendo, o conhecimento do ritmo de crescimento de cada constituinte corporal, do ponto de vista econômico, pode possibilitar a determinação, com maior precisão, do peso ótimo para abate para cada grupo genético, viabilizando a máxima valorização do produto, sendo que a perna, entre os cortes da carcaça, é considerada a mais nobre pelo fato dela apresentar maior acúmulo de massas musculares (Monteiro et al., 1999).

Rohr \& Daenicke (1984), citaram que a influência da raça utilizada nos cortes comerciais é um fator importante e que afeta a distribuição dos pesos relativos dos diferentes cortes da carcaça. Com o aumento do peso de abate, ocorrem variações positivas e negativas na proporção destes cortes na carcaça.

Os consumidores consideram importante a composição em osso, músculo e gordura, pois, devido à maior preocupação com a saúde, procuram adquirir um produto que contenha mais músculo e menor quantidade de osso e gordura. Entretanto, não somente o consumidor, como também para o produtor, o conhecimento da composição da carcaça e de seus cortes nobres é fundamental para comercializar no mercado produtos de qualidade que tragam maior retorno e melhor valorização dos produtos (Furusho-Garcia et al., 2003). 


\subsubsection{Perda de peso no resfriamento da carcaça}

O método mais utilizado e tradicional para a conservação de carnes é o resfriamento, sendo amplamente utilizado em todas as partes do mundo. O princípio básico se dá pela redução da temperatura, bloqueando o desenvolvimento de microorganismos patogênicos e deteriorantes, e retardando atividades enzimáticas que contribuem para alterações físicas e organolépticas, promovendo assim o prolongamento da vida de prateleira dos produtos (Stevenson et al., 1978).

A perda de peso pelo resfriamento ocorre devido à perda de umidade da carcaça na câmara fria durante o processo de resfriamento após o abate (Kirton, 1968). O grau destas perdas está ligado diretamente a dois fatores: a gordura de cobertura, onde forma uma camada protetora, e dependendo da sua espessura, determina maior ou menor porcentagem de perda; e a umidade relativa da câmara fria, que deve ser controlada visando menores perdas.

O valor de literatura mais comumente é de $4 \%$ de umidade relativa, porém essa porcentagem pode variar devido a alguns fatores como peso ao abate e grau de cobertura da carcaça (Silva Sobrinho, 2001).

\subsection{4 Área de olho de lombo (AOL)}

Das partes que compõe a carcaça, a de maior interesse para o consumidor é a carne. A análise da área de olho-de-lombo (AOL), mensurada no músculo Longissimus dorsi é considerada uma medida representativa da quantidade e da distribuição da carne na carcaça, assim como a sua qualidade. Os músculos de maturidade tardia são indicados para representar o índice do desenvolvimento e tamanho do tecido muscular; sendo assim, o Longissimus dorsi é o mais indicado, pois, além do amadurecimento tardio, é de fácil mensuração (Sainz, 1996).

Sendo assim, a avaliação desta característica fornece subsídios para estabelecer padronização de cortes em relação ao tamanho, composição química e avaliações sensoriais.

\subsection{Aspectos qualitativos da carcaça}

\subsubsection{Avaliação do $\mathrm{pH}$ na carcaça}

$\mathrm{O}$ pH é de fundamental importância para o processo de transformação do músculo em carne e sobre as propriedades tecnológicas da carne. $\mathrm{O} \mathrm{pH}$ final influi 
diretamente nas características qualitativas da carne, devido ao seu valor final demonstrar diretamente as características desejáveis de uma carne normal. Conforme diminui o pH, aproximando-se do ponto isoelétrico das proteínas miofibrilares, as repulsões eletrostáticas entre proteínas diminuem e a quantidade de água entre elas fica menor.

A carne pode ser definida como o produto resultante de diversas transformações que ocorrem no músculo após a morte do animal. Geralmente, o pH do músculo após o abate do animal diminui de aproximadamente 7 para 5,5; devido ao acúmulo de glicogênio neste período (ante mortem), ocasionando a transformação em ácido láctico, causada pela ausência de oxigênio nas células, e resultando em reações bioquímicas post mortem que geram a transformação de músculo em carne. $\mathrm{O}$ pH é capaz de modificar as características de qualidade da carne (cor, capacidade de retenção de água e maciez), além de alterar suas características organolépticas (Bonagurio et al., 2003). A queda de pH é importante para a conservação e qualidade da carne, pois, essa queda, impede que bactérias causadoras da decomposição e putrefação encontrem condições adequadas para sua multiplicação (Yamamoto, 2006).

Alterações do pH estão relacionadas com a produção de ATP durante o período post mortem, mantida graças às reservas de nutrientes, especialmente de glicogênio estocado nas mioglobinas, da célula. Para obtenção de energia necessária à manutenção de sua integridade celular após a sangria, o músculo degrada o glicogênio e produz ATP, utilizando o mecanismo aeróbio (oxidativo) enquanto possuir reservas de oxigênio estocadas nas mioglobinas. O mecanismo imediato de produção de energia é limitado e cessa quando esgotam suas reservas, não renovadas com o término do mecanismo aeróbio.

Entretanto, exauridas as reservas de oxigênio (não renovadas em decorrência da falência da circulação sanguínea) presentes nas mioglobinas, a resíntese muscular de ATP passa a ser realizada exclusivamente pela via anaeróbica, resultando na produção do ácido lático, a partir do ácido pirúvico, para manter o sistema redutor da célula. Uma vez que não há sistema circulatório para removê-lo, o ácido lático formado se acumula no músculo, gerando redução do pH muscular (Ramos, 1973).

O ácido lático continuará sendo produzido e se acumulando no músculo, até que todo glicogênio estocado seja consumido ou até que o pH muscular se torne tão baixo que as próprias enzimas glicolíticas ssão inativadas. $\mathrm{O}$ abaixamento do $\mathrm{pH}$ muscular, devido ao acúmulo de ácido lático, é uma das mudanças bioquímicas mais significativas que aparecem durante sua conversão em carne. No animal vivo o pH se encontra em níveis fisiológicos, ou 
seja, entre 6,8 e 7,2, mas 24 horas após o abate, em uma acidificação adequada, os valores de pH da carne situam-se entre 5,5 e 5,8.

$\mathrm{Na}$ acidificação, não só o valor de $\mathrm{pH}$ final é importante, mas também a velocidade com que este é atingido (taxa de declínio de $\mathrm{pH}$ ), visto que tem influência determinante na qualidade final da carne. Tanto a taxa de declínio do $\mathrm{pH}$ como o seu valor final pos mortem influenciam na qualidade da carne, o que afeta diretamente na sua aparência, conservação, propriedades tecnológicas, como a capacidade emulsificante de retenção de água (CRA), tendo reflexos diretos e indiretos na maciez, sabor, rendimento e valor nutricional da carne. Assim, alguns dos principais defeitos associados as carnes in natura dizem respeito a obtenção de carnes que apresentam curvas anormais (não usuais ou indesejadas) de queda de pH post mortem (Ramos, 1973).

A carne de corte escuro (dark, cutting) ou ainda DFD (dark, firm and dry), apresenta características anormais devido ao seu aspecto, escuro, firma e seco, apresentando pouca exudação de água na carne, devido a sua maior CRA, já que a pequena queda post mortem do $\mathrm{pH}$ muscular causa pouca desnaturação das proteínas miofibrilares responsáveis pela ligação de água na fibra muscular; isso implica uma superfície de corte mais seca que aquela de uma carne normal RFN (red, firm and normal), que se apresenta mais úmida.

A carne DFD é um problema causado pelo estresse crônico (cansaço, maustratos, excitação), induzido antes do abate, especialmente quando esta condição é prolongada, como nas etapas relacionadas ao embarque, transporte e desembarque dos animais. Através do $\mathrm{pH}$, a diferenciação entre carnes DFD e normal RFN poderá ocorrer especialmente 24 horas após o abate. Os valores de pH em que se caracteriza a carne como DFD são variáveis entre países e indústrias e, mesmo, entre pesquisadores. No entanto, embora carnes com valores de pH final acima de 6,0 possam ser consideradas como carnes DFD, as de valores acima de 6,2, são consideradas DFD clássico. A maioria dos países importadores, por exemplo, exige carnes ovinas com valores de $\mathrm{pH}$ final menores que 5,9 (Ramos, 1973).

\subsubsection{Avaliação da cor da carne}

A cor é a característica mais importante para o consumidor no momento da compra e reflete o estado químico e o teor de mioglobina no músculo (Bonagurio et al., 2003). Normalmente, carnes escuras são rejeitadas pelo consumidor, que associa a cor escura a carnes com maior vida útil ou provenientes de animais mais velhos (Bonacina et al., 2011). 
O estresse pré-abate, a idade e o tratamento pós-abate são fatores que podem afetar a cor do músculo (Bressan et al., 2001).

Mioglobina $(\mathrm{Mb})$ e hemoglobina são pigmentos de cor das carnes: enquanto a primeira retém o oxigênio no músculo, a segunda o transporta na corrente sanguínea. A mioglobina tem o papel de armazenar o oxigênio no músculo e o transferir ao sistema citocromo-oxidase intracelular. É uma cromoproteína formada por um grupo proteico, e outro prostético, que se compõe de um átomo de ferro ao qual se fixa o oxigênio e uma protoporfirina (Bonagurio et al., 2003).

$\mathrm{Na}$ carne fresca, em condições normais, a mioglobina pode se apresentar em três formas básicas e a cor variará segundo a proporção relativa e a distribuição desses pigmentos: (1) mioglobina reduzida ou desoximioglobina (ferro ferroso, $\mathrm{Fe}++$ ), $\mathrm{Mb}$, de cor vermelho-púrpura, encontra-se no interior da carne, resiste mesmo depois da morte pela própria atividade redutora do músculo, ocorrem em carnes embaladas à vácuo; (2) oximioglobina ou mioglobina oxigenada (ferro ferroso, $\mathrm{Fe}++$ ), $\mathrm{MbO}_{2}$, formada quando a $\mathrm{Mb}$ entra em contato com o ar, com a consequente oxigenação do pigmento, tem cor vermelhobrilhante, é a clororação desejável pelo consumidor, por isto estamos sempre buscando sua obeservação; (3) metamioglobina ou mioglobina oxidada (ferro férrico, Fe+++), MetMb, forma-se por exposição prolongada da anterior ao oxigênio ou diretamente a partir da mioglobina reduzida quando as pressões de oxigênio são baixas (cerca de $4 \mathrm{~mm}$ ), como pode ocorrer nas embalagens inadequadas, que permitem a passagem de oxigênio, é de cor marrom-pardo e motivo de recusa pelo consumidor (Almeida Júnior, 2004).

\subsubsection{Força de cisalhamento}

A força de cisalhamento tem sido usada como forma de avaliação da maciez da carne (Menezes et al., 2009). Segundo Yamamoto (2006), a maciez pode ser definida como a facilidade de mastigar a carne com sensações de penetração e corte, resistência à ruptura e presença de resíduos, estando relacionada com a capacidade de retenção de água, pH, estado de engorduramento e características do tecido conjuntivo e da fibra muscular.

Alguns fatores afetam a maciez da carne, dentre os quais devem ser destacados a dieta, idade ao abate, genótipo, sexo e armazenamento da carne (Silva et al., 2008). A maciez da carne está diretamente relacionada às estruturas proteicas e aos tecidos conjuntivos e musculares, exigindo maior importância para o tecido conjuntivo do que para a fibra muscular. O tecido conjuntivo tem duas proteínas fibrilares - colágeno e elastina; o colágeno 
é o principal pela "dureza de base" da carne, já que quase não é afetada pela maturação (Ramos, 1973).

O tecido muscular influi sobre a dureza da carne, em função da natureza e atividade de suas proteínas (miofibrilares e citoplasmáticas). As miofibrilares são responsáveis pela instauração do rigor mortis, pela contração das cadeias de miosina e actina. Por outro lado, as proteínas citoplasmáticas são responsáveis pelo processo de maturação ou amaciamento pós-morte e especialmente os dois sistemas proteolíticos, catepsinas e calpaínas, assim como seus inibidores específicos, as calpastatinas; ocorrendo uma relação direta entre o teor de calpastatina e maior dureza.

O tecido adiposo influi sobre a maciez a partir da gordura intramuscular e, dependendo do tamanho do corte, também a gordura intermuscular terá importância, já que o aumento desta desenvolve aparente sensação de suculência, como se pode observar nos estudos de Bonacina et al. (2011), em que as fêmeas apresentaram carne mais macia que os machos e com maior quantidade de gordura intramuscular (fêmeas $=4,01 \%$ de gordura e machos $=2,93 \%$ de gordura).

\subsubsection{Perdas por cocção}

A perda por cocção é uma medida de qualidade, que está associada ao rendimento da carne no momento do consumo, sendo uma característica influenciada pela capacidade de retenção de água nas estruturas da carne (Monte et al., 2012). É importante por influenciar as características de qualidade, cor, força de cisalhamento e suculência da carne. A perda de peso na cocção varia segundo o genótipo, condições de manejo pré e pós-abate e a metodologia no preparo das amostras, tais como a remoção ou padronização da gordura subcutânea e do tipo de equipamento, fatores que podem levar a variação da temperatura no processo de cocção.

O processo de cocção da carne altera os teores de proteína, gorduras, cinzas e matéria seca devido à perda de nutrientes e água durante o processo (Pinheiro et al., 2008; Rosa et al., 2006). A cocção dos alimentos proporciona trocas físicas, químicas e estruturais de seus componentes pelo efeito do calor. As formas de transferência de calor, a temperatura, meio de cocção, a duração do processo para o preparo da carne são alguns dos fatores responsáveis pelas alterações químicas e físicas que podem modificar a composição química e o valor nutricional da mesma. 


\section{REFERÊNCIAS BIBLIOGRÁFICAS}

ALMEIDA JÚNIOR, G.A.; COSTA, C.; MONTEIRO, A.L.G.; GARCIA, C.A.; MUNARI, D.P.; NERES, M.A. Qualidade da carne de cordeiros criados em creep-feeding com silagem de grãos úmidos de milho. Revista Brasileira de Zootecnia, Viçosa, V.33, n.4, p. 1039-1047, 2004.

ALMEIDA, H.S.L. Produção de carne de cordeiros da raça Ideal e cruzas Ideal x Border Leicester terminados em campo natural suplementado ou pastagem cultivada com ou sem suplementação. Dissertação (Mestrado em Zootecnia). Universidade Federal de Santa Maria, 99p., 2004.

ARAUJO FILHO, J.T.; COSTA, R.G.; FRAGA, A.B.; SOUSA, W.H.; CEZAR, M.F. Desempenho e composição da carcaça de cordeiros deslanados terminados em confinamento com diferentes dietas. Revista Brasileira de Zootecnia, v.39, n.2, p.363-371, 2010.

AZZARINI, M. Produção de carne ovina. $1^{a}$ Jornada Técnica de Produção Ovina no RS. Bagé-RS-Brasil. P. 49-63. 1979

BARBOSA, J.A. Evolução da Raça Santa Inês: Panorama mercadológico de reprodutores e matrizes. IV Simpósio Mineiro de Ovinocultura, 2005.

BONACINA, M.S.; OSÓRIO, M.T.M.; OSÓRIO, J.C.S.; CORRÊA, G.F.; HASHIMOTO, J.H. Influência do sexo e do sistema de terminação de cordeiros Texel x Corriedale na qualidade da carcaça e da carne. Revista Brasileira de Zootecnia, v.40, n.6, p.1242-1249, 2011.

BONAGURIO,S.; PÉREZ, J.R.O.; GARCIA, I.F.F.; BRESSAN, M.C.; LEMOS, A.L.S.C. Qualidade da carne de cordeiros Santa Inês puros e mestiços com Texel abatidos com diferentes pesos. Revista Brasileira de Zootecnia, v.32, n.6, p.1981-1991, 2003 (Suplemento).

BRAGA, R.M. Criação de ovinos: Orientações básicas para o produtor. Documento 46, EMBRAPA. Roraima, 2011, 24p.

BRESSAN, C.; PRADO, O.V.; PÉREZ, J.R.O. et al. Efeito do peso ao abate de cordeiros Santa Inês e Bergamácia sobre as características físico-químicas da carne. Ciência e Tecnologia de Alimentos, v.21, n.3, p.293-303, 2001.

BRITO M.A. Variação dos perfis metabólico, hematológico e lácteo de ovinos leiteiros em confinamento. Rio Grande do Sul, 2004. 100p. Tese de doutorado. Universidade Federal do Rio Grande do Sul - UFRGS, 2004. 
BUENO, M.S.; CUNHA, E.A.; SANTOS, L.E. et al. Características de carcaça de cordeiros Suffolk abatidos em diferentes idades. Revista Brasileira de Zootecnia, v. 29, n. 6, p. 1803 1810, 2000.

Caprileite - ACCOMIG - Associação de Criadores de Caprinos e Ovinos de Minas Gerais. 2014. Disponível em: < http://www.caprileite.com.br/racas1.php?id_racas=4\&tipo=Ovinos>. Acesso em: 06/07/2014.

CARDELINO, R.A. Sistemas de produção de carne ovina utilizando cruzamentos. In: SIMPÓSIO PAULISTA DE OVINOCULTURA, 1, 1988, Botucatu, Anais... Campinas: Cargill, p.97, 1989.

CARNEIRO, P.L.S.; MALHADO, C.H.M.; SOUZA JÚNIOR, A.A.O. et al. Desenvolvimento ponderal e diversidade fenotípica entre cruzamentos de ovinos Dorper com raças locais. Pesquisa Agropecuária Brasileira, v.42, n.7, p.991-998, 2007.

FAO. FOOD AND AGRICULTURE ORGANIZATION OF THE UNITED STATES. FAOSTAT, disponível em: <http://faostat.fao.org/site/569/DesktopDefault.aspx?PageID=569\#ancor > Acesso em: 04/05/2014.

FIGUEIREDO, E.A.P. Potencial genotypes for Morada Nova sheep in Northest em Brazil. Journal of Animal Science. v.67, n.8, p. 1956-1963, 1989.

FIGUEIRÓ, P.R.P. Efeito do cruzamento da raça Hampshire Down e Romney Marsh na produção de cordeiros para abate. Revista do Centro de Ciências Rurais, v.9, p. 421-428, 1979.

FURUSHO-GARCIA, I. F. Desempenho de cordeiros Santa Inês puros e cruzas Santa Inês com Texel, Ile de France e Bergamácia. Revista Brasileira de Zootecnia. v.33, n.6, p.15911603, 2004.

GARCIA, C.A. Avaliação do resíduo de panificação "biscoito" na alimentação de ovinos e nas características quantitativas e qualitativas da carcaça. Jaboticabal: Universidade Estadual Paulista, 1998. 79p. Dissertação (Mestrado em Zootecnia) - Universidade Estadual Paulista, 1998.

IBGE - INSTITUTO BRASILEIRO DE GEOGRAFIA E ESTATÍSTICA. 2012. Disponível em: <http://www.sidra.ibge.gov.br> Acesso em: 05/05/2014.

KIRTON, A.H. Animal Industries Workshop Lincoln College, Technical Handbook (lamb growth - carcass composition). 2.ed. Canterbury: Lincoln College, 1986. p.25-31.

MACHADO, R.; SIMPLICIO, A.A.; BARBIERI, M.E. Acasalamento entre ovelhas deslanadas e reprodutores especializados para corte: desempenho produtivo até a desmama. Revista Brasileira de Zootecnia, v.28, n.4, p.706-716, 1999.

MADRUGA, M.S.; ARAÚJO, W.O.; SOUSA, W.H. et al. Efeito do genótipo e do sexo sobre a composição química e o perfil de ácidos graxos da carne de cordeiros. Revista Brasileira de Zootecnia, v.35, n.4 (suplemento), p.1838-1844, 2006. 
MARTINEZ, D. E.; NUÑEZ, F. A. G.; GARCÍA, A. M.; BLANCA, A. T. Caracterización de canales de borregos alimentados con desechos de papel. Revista Brasileira de Agrociência, Pelotas, v. 7, n. 1, p. 50-53, 2001

MEDEIROS, G.R. Efeito de níveis de concentração sobre o desempenho, características de carcaça e componentes não carcaça de ovinos Morava Nova em confinamento. Recife: Universidade Federal Rural de Pernambuco, 2006 108p. Tese (Doutorado em Zootecnia) Universidade Federal Rural de Pernambuco, 2006.

MEDEIROS, J.X.; SANTO, E.E.; COSTA, N.G.; RIBEIRO, J.G.B.L. Cenário mercadológico da ovinocultura. In: Simpósio Mineiro de Ovinocultura, IV ${ }^{\circ}$, Lavras, Minas Gerais. 2005. Anais... 18 p., 2005

MENEZES, J.J.L.; GONÇALVES, H.C.; RIBEIRO, M.S.; RODRIGUES, L.; CAÑIZARES, G.I.L.; MEDEIROS, B.B.L. Efeitos do sexo, do grupo racial e da idade ao abate nas características de carcaça e maciez da carne de caprinos. Revista Brasileira de Zootecnia, v.38, n.9, p.1769-1778, 2009.

MONTE, A.L.S.; GONSALVES, H.R.O.; VILLARROEL, A.B.S.; DAMACENO, M.N.; CAVALCANTE, A.N.D. Qualidade da carne de caprinos e ovinos: uma revisão. Revista Agropecuária Científica no Semi-Árido, v.8, n.3, p11-17, 2012

MOTTA, O.S.; PIRES, C.C.; SILVA, J.H.S. et al. Avaliação de carcaça de cordeiros da raça Texel sob diferentes métodos de alimentação de pesos de abate. Ciência Rural, v. 31, n. 6, p. 1051-1056, 2001.

MULTIMEAT. 2008. Disponível em: http://www.multimeat.com.au/index.html. Acesso em: 10/07/2013.

NOTTER, D.R. Development of sheep composite breeds for lamb production in the tropic and subtropics. In: SIMPOSIO INTERNACIONAL SOBRE CAPRINOS E OVINOS DE CORTE, 1., 2000. João Pessoa. Anais... João Pessoa: Emepa PB,p.141-150, 2000

OLIVEIRA, M.V.M.; PÉREZ, J.R.O.; ALVES, E.L. et al. Rendimento de carcaça, mensurações e peso de cortes comerciais de cordeiros Santa Inês e Bergamácia alimentados com dejetos de suínos em confinamento. Revista Brasileira de Zootecnia, v.31, n.3, p.14511458, 2002 (suplemento).

OSÓRIO, M.T.M.; SIERRA, I.; SANUDO, C. et al. Influência da raça, sexo e peso/idade sobre o rendimento de carcaça em cordeiros. Ciência Rural, v.29, n.1, p.139-142, 1999.

PÉREZ, J.R.O. Alguns aspectos relacionados com a qualidade da carcaça e da carne ovina. In: SIMPÓSIO PAULISTA DE OVINOCULTURA, 4., 1995, Campinas. Anais... Campinas: 1995. p.125-139.

PINHEIRO, R. S. B; JORGE, A. M; FRANCISCO, C. L; et al. Composição química e rendimento da carne ovina in natura e assada. Ciência e Tecnologia de Alimentos. Campinas, v.28, p.154-157, 2008. (suplemento) 
RAMOS, EDUARDO MENDES, 1973. Avaliação da qualidade de carnes: fundamentos e metodologias/ Eduardo Mendes Ramos, Lúcio Alberto de Miranda Gomide - Viçosa, MG. $599 \mathrm{p}$.

RIBEIRO, T.M.D. Características da pastagem de azevém e produtividade de cordeiros em pastejo. Revista Brasileira de Zootecnia, v.38, n.3, p.580-587, 2010.

RODRIGUES, S.; CADAVEZ, V.; TEIXEIRA, A. Breed and maturity effects on Churra Galega Bragançana and Suffolk lamb carcass characteristics: killing-out proportion and composition. Meat Science, v.72, p.288-293, 2006

SANTOS, V.T. 1986. Ovinocultura. Princípios básicos para sua instalação exploração. São Paulo: Nobel. 167p

ROSA, F. C; BRESSAN, M. C; BERTECHINI, A. G; et al. Efeito de métodos de cocção sobre a composição química e colesterol em peito e coxa de frangos de corte. Revista Ciência Agrotécnica, v. 30, n. 4, p. 707-714, 2006.

ROSANOVA, C.; SILVA SOBRINHO, A.G.; GONZAGA NETO, S. Raça Dorper e sua caracterização produtiva e reprodutiva. Revista Veterinária Notícias, Uberlândia, v. 11, n. 1, p. 127-135, 2005.

SAINZ, R.D. Qualidade das carcaças e da carne ovina e caprina, In: REUNIÃO ANUAL DA SOCIEDADE BRASILEIRA DE ZOOTECNIA, 33, 1996, Fortaleza. Anais... Fortaleza: Sociedade Brasileira de Zootecnia, p.3-14, 1996.

SANTOS, C.L. Estudo do Crescimento e da composição química dos cortes da carcaça de cordeiros Santa Inês e Bergamácia. Lavras: Faculdade de Zootecnia, 2002. 257p. Tese (Doutorado em Zootecnia) - Faculdade de Zootecnia da Universidade Federal de Lavras, 2002.

SANUDO, C. La calidad organoleptica de la carne com especial referencia a La espécie ovina. Factores que la determinan, métodos de medida y causas de variación. In: Curso International sobre Producción de Ganado Ovino, III ${ }^{\circ}$, I.C.I., I.N.I.A., S.I.A. - D.G.A., Zaragoza, Espana. 117 p. 1991.

SAÑUDO, C. Manual de diferenciación racial. Ed. SERVET, Zaragoza, Espanha. 2008. $558 \mathrm{p}$.

SIMPLÍCIO, A.A. A caprino-ovinocultura na visão do agronegócio. Revista CFMV, n.24, p.15-18, 2001

SIDWELL, G.M., MILLER, L.R. Production in some pure breeds of sheep and their crosses. Journal Animal Science, v.32, p.1090-1094, 1971.

SILVA SOBRINHO, A.G. Criação de ovinos. 2.ed. Jaboticabal: Funep, 2001. 301p.

SILVA SOBRINHO, A.G.; SILVA, A.M.A. Produção de carne ovina - Parte II. Artigo Técnico. Revista Nacional da Carne, n.286, p.30-36, 2000. 
SILVA, N.V.; SILVA, J.H.V.; COELHO, M.S. Características de carcaça e carne ovina: uma abordagem das variáveis metodológicas e fatores de influência. Acta Veterinaria Brasilica, v.2, n.4, p.103-110, 2008.

SOUSA, W. H. Desempenho e característica de carcaça de cordeiros terminados em confinamento com diferentes condições corporais. Revista Brasileira de Saúde e Produção Animal, v.9, n.4, p.795-803, 2008.

SOUSA, W.H.; LÔBO, R.N.B.; MORAIS, O.R. Ovinos Santa Inês: Estado e Arte e Perspectivas. In: II SIMPÓSIO INTERNACIONAL SOBRE CAPRINOS E OVINOS SINCORTE, 2003. João Pessoa - PB Anais... João Pessoa: SINCORTE, p. 501 - 521, 2003.

SOUZA, E.Q. Análise e segmentação de mercado da ovinocultura do Distrito Federal. Brasília: Faculdade de Agronomia e Medicina Veterinária, 2006.103p. Dissertação (Mestrado) Faculdade de Agronomia e Medicina Veterinária da Universidade de Brasília da Brasília, 2006.

STEVENSON, K.E.; MERKEL, R.A.; LEE, H.C. Effects of chilling rate, carcass fatness and cholorine spray on microbiological quality and case-life of beef. Journal of Food Science, v.43, n.2, p.94-99, 1978.

VIEIRA, G.V.N. Criação de Ovinos. $3^{\text {a }}$ Ed. Edições Melhoramentos, São Paulo, SP, 1967. 480p.

YAMAMOTO, S.M. Desempenho e características da carcaça e da carne de cordeiros terminados em confinamento com dietas contendo silagens de resíduos de peixes. Dissertação (Doutorado em Zootecnia) Faculdade de Ciências Agrárias e Veterinárias Unesp, Campus de Jaboticabal, 2006.

ZUNDT, M.; MACEDO, F.A.F.; MARTINS, E.N. et al. Características de carcaça de cordeiros terminados em confinamento, com dietas contendo diferentes níveis protéicos. Ciência Rural, v.33, n.3, p. 565-571, 2003. 


\section{CAPÍTULO 2}

DESEMPENHO E CARACTERÍSTICAS QUANTITATIVAS DA CARCAÇA DE CORDEIROS DE DIFERENTES GRUPOS GENÉTICOS 


\section{RESUMO}

Objetivou-se avaliar o desempenho e as características quantitativas da carcaça de cordeiros de três diferentes grupos genéticos e dois tipos de parto terminados em sistema de confinamento. Utilizou-se 24 cordeiros, machos, não castrados, de diferentes grupos genéticos formados pelo cruzamento das raças Santa Inês (SI) x White Dorper (WD), SI x Lacaune, SI x Multimeat. Os animais, distribuídos em delineamento inteiramente casualizado em arranjo fatorial 3 X 2 ( 3 grupos genéticos e 2 tipos de parto), foram confinados em baias individuais e alimentados com ração composta de silagem de milho e concentrado (25:75). Os animais foram abatidos ao atingirem peso corporal médio de $39,26 \mathrm{~kg}$. Não houve efeito na interação entre grupo genético e tipo de parto em todas as variáveis avaliadas. Entre os grupos genéticos, observou-se que os animais do cruzamento SI x WD apresentaram maior consumo de matéria seca. Houve diferença entre o tipo de parto, sendo obsevados valores superiores para as variáveis peso corporal inicial e final, consumo de matéria seca e eficiência alimentar nos animais nascidos de parto simples. Já os animais de parto duplo apresentaram maior área de olho de lombo e maior peso da paleta, lombo, perna e cortes nobres. Os cordeiros oriundos do cruzamento de fêmeas da raça Santa Inês com machos das raças Dorper, Lacaune ou Multimeat apresentaram excelentes desempenhos produtivos e características quantitativas de carcaça, sendo indicados para serem utilizados como alternativa de cruzamento industrial para terminação em confinamento.

Palavras-chave: cor, lacaune, multimeat, tipo de parto, white dorper. 


\section{ABSTRACT \\ PERFORMANCE AND QUANTITATIVE CARCASS CHARACTERISTICS OF LAMBS FROM DIFFERENT GENETIC GROUPS}

It aimed to evaluate the performance and quantitative characteristics of the carcass lambs of three different genetic groups and two types of parturition in feedlot system. We used 24 lambs, male, uncastrated, of different genetic groups formed by the intersection of Santa Inês (SI) x White Dorper (WD), SI x Lacaune, SI x Multimeat. The animals, in a completely randomized design in a factorial arrangement $3 \times 2$ (3 genetic groups and two types of parturition) were housed in individual pens and fed with feed consisting of corn silage and concentrate (25:75). The animals were slaughtered when they reached average body weight of $39.26 \mathrm{~kg}$. There was no effect on the interaction between genetic group and type of parturition in all variables. Among the genetic groups, it was observed that the animals in the SI x WD crossing had higher dry matter intake. There was a difference between the type of delivery, and higher values for the variables initial and final body weight, dry matter intake and feed efficiency in the simple delivery of animals born. Already the twin birth of animals had greater loin eye area and greater weight palette, loin, leg and prime cuts. The lambs coming from the female race crossing Santa Inês with males of White Dorper, Lacaune or Multimeat showed excellent production performance and quantitative characteristics of housing, it is indicated for use as industrial crossing alternative to feedlot finished.

Key-words: color, lacaune, multimeat, parturition, performance, White Dorper. 


\section{INTRODUÇÃO}

A qualidade da carne ovina, no Brasil, ainda é fator que favorece o baixo consumo, o qual está relacionado principalmente com a qualidade do produto colocado à venda, proveniente de animais velhos que produzem carcaças e seus componentes de baixa qualidade (Azzarini, 1979; Santos, 1986).

Os cordeiros são a categoria ovina cuja carne tem maior aceitabilidade pelo mercado consumidor, haja vista suas melhores características de carcaça e a melhor qualidade de sua carne (Pires et al., 2006). O peso e idade de abate ideal variam muito entre as raças ovinas; no entanto, deve-se procurar abater animais mais jovens, com características de carcaça que atendam às exigências do consumidor, pois, com o avançar da idade, o animal tende a depositar menor quantidade de proteína, enquanto a de lipídio aumenta (Cunha et al., 2008).

Os cruzamentos industriais constituem um sistema de comprovada eficiência em países produtores de carne ovina, tendo como base três processos biológicos principais: eficiência reprodutiva da raça utilizada, velocidade de crescimento e nível de nutrição disponível (Figueiró, 1979). Os cruzamentos industriais são utilizados, entre outros motivos, para obtenção de carcaça com melhor conformação e, consequentemente, com melhor qualidade.

O sistema de terminação de cordeiros em confinamento é uma prática bastante utilizada nas produções mais intensificadas, pois proporciona retorno econômico satisfatório com a diminuição da idade ao abate, promovendo maior ganho de peso em menor tempo, com características de carcaça desejáveis para o mercado consumidor (Ortiz et al., 2005).

A avaliação de carcaça é uma importante ferramenta para alcançar a melhoria nos produtos ofertados. Entre os fatores que influenciam as características de carcaça, destacam-se o genótipo e o sistema de terminação. Portanto, é necessária uma avaliação das características quantitativas de carcaça dentro dos grupos genéticos, principalmente naqueles que são utilizados em cruzamento industrial. 
Assim, o objetivo neste trabalho foi avaliar o desempenho e as características quantitativas da carcaça de cordeiros Santa Inês x White Dorper, Santa Inês x Lacaune, Santa Inês x Multimeat em dois tipos de parto (simples e duplo), terminados em confinamento. 


\section{MATERIAL E MÉTODOS}

O experimento foi realizado por 98 dias (23 de outubro a 29 de janeiro de 2013) no Centro de Manejo de Ovinos (CMO), da Fazenda Água Limpa (FAL), pertencente à Universidade de Brasília (UnB), situada nacidade de Brasília-DF. O clima da região é do tipo AW pela classificação de Koppen, com temperatura média anual de $23{ }^{\circ} \mathrm{C}$, com mínima de 16 e máxima de $34^{\circ} \mathrm{C}$. A precipitação anual é de $1.300 \mathrm{~mm}$ e a média anual de umidade relativa do ar é de $66 \%$.

Foram utilizados 24 cordeiros machos inteiros de três diferentes grupos genéticos (1. Santa Inês x White Dorper, 2. Santa Inês x Lacaune e 3. Santa Inês x Multimeat) e dois tipos de parto (simples ou duplo), distribuídos em delineamento inteiramente casualizado (DIC), em arranjo fatorial 3 x 2 (três grupos genéticos e dois tipos de parto.

Os animais iniciaram o experimento com o peso médio de $15 \mathrm{Kg}$ e idade média de 70 dias, sendo vermifugados antes do início do experimento. Os cordeiros foram mantidos em sistema de confinamento, distribuídos em baias individuais providas de comedouro e bebedouro, alocadas em um prédio de alvenaria, com cobertura metálica e contendo cortinas móveis para evitar incidência de chuvas e ventos fortes (Figura 2.1).

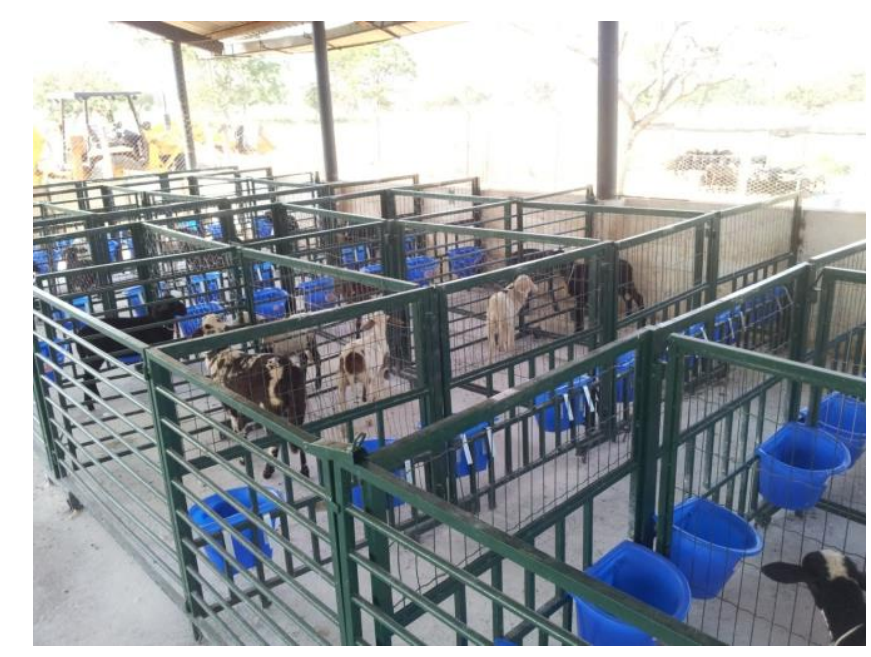

Figura 2.1: Instalações experimentais. Fonte: Arquivo pessoal. 
Foram 20 dias de adaptação à dieta e às condições de instalações e 78 dias divididos em três períodos de 26 dias experimentais. Os animais foram pesados no início do experimento e no final de cada período experimental.

Os animais experimentais foram alimentados com ração composta de silagem de milho e concentrado contendo farelo de milho (68,2\%), farelo de soja $(27,8 \%)$ e núcleo mineral (4\%), cuja análise bromatológica encontra-se na Tabela 2.1. A relação volumoso:concentrado foi de 25:75, apresentando média de 16\% de Proteína Bruta (PB) e 75\% de Nutrientes Digestíveis Totais (NDT). A ração total foi formulada de acordo com recomendações do AFRC (1998) para atender as exigências nutricionais em proteína e energia metabolizável de cordeiros em crescimento e proporcionar ganhos de peso em torno de 300 g/dia.

Tabela 2.1. Composição bromatológica da dieta fornecida aos animais (\% da matéria seca)

\begin{tabular}{lcccccc}
\hline Ingrediente & MS & PB & FDN & FDA & EE & MM \\
\hline Milho moído & 88,00 & 8,50 & 12,00 & 5,00 & 3,28 & 2,20 \\
Farelo de Soja & 90,00 & 45,00 & 14,12 & 4,2 & 0,90 & 5,40 \\
\cline { 2 - 7 } & \multicolumn{7}{c}{ Volumoso } \\
\hline Silagem de Milho & 45,00 & 6,50 & 59,00 & 29,47 & 3,15 & 3,25 \\
\hline
\end{tabular}

Núcleo mineral: cálcio (mín) 120g; cálcio (máx) 250g; fósforo (mín) 65g; enxofre (mín) 85g; cobalto (mín) 8,5mg; sódio (mín) 110g; iodo (mín) 34mg; cobre (mín) 30mg; manganês (mín) 1750mg; selênio (mín) 18mg; zinco (mín) 2250mg; ferro (mín) 1600mg; vitamina A (mín) 90.000 UI; vitamina D (mín) 18.000 UI; vitamina E (mín) 290mg.

A ração foi fornecida duas vezes ao dia (4\% de MS em relação ao peso vivo), às 9:00 e 17:00 horas. As sobras foram retiradas diariamente antes do fornecimento da ração na parte da manhã e pesadas (Figura 2.2), visando o monitoramento da quantidade consumida e o cálculo da quantidade fornecida, proporcionando em torno de $15 \%$ de sobras. 


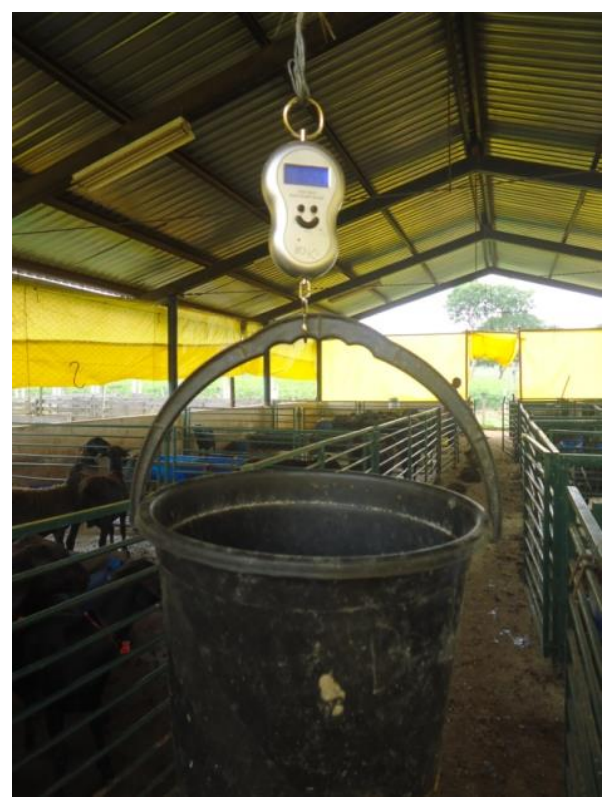

Figura 2.2: Pesagem das sobras. Fonte: Arquivo pessoal.

Os animais foram abatidos com peso vivo médio ao abate (PVA) de 39,26 kg, após jejum de aproximadamente 16 horas de dieta sólida, em um frigorífico comercial localizado em Samambaia/DF que possui fiscalização do Departamento de Inspeção de Produtos de Origem Vegetal e Animal (DIPOVA/MAPA), seguindo as normas de abate humanitário.

Após realização da esfola e evisceração, as carcaças foram pesadas para obtenção do peso da carcaça quente (PCQ). Após 24 horas na câmara fria a $4^{\circ} \mathrm{C}$, as carcaças foram novamente pesadas para obtenção do peso da carcaça fria (PCF). A porcentagem de perda por resfriamento $(\mathrm{PR})$ foi calculada pela fórmula: PR $(\%)=((\mathrm{PCQ}-\mathrm{PCF}) / \mathrm{PCQ}) \times 100$. Em seguida foram determinados os rendimentos de carcaça quente (RCQ) e de carcaça fria $(\mathrm{RCF})$, respectivamente, pelas seguintes fórmulas: $\mathrm{RCQ}=(\mathrm{PCQ} / \mathrm{PVA}) \times 100, \mathrm{RCF}=$ (PCF/PVA) x100. O índice de compacidade da carcaça (ICC) foi realizada seguindo metodologia descrita por Sañudo \& Sierra (1986), utilizando-se a fórmla: $\mathrm{ICC}=\mathrm{PCF} /$ comprimento interno da carcaça, sendo o comprimento interno medido pela distância máxima entre o bordo anterior da sínfise ísquio-pubiana e o bordo anterior da primeira costela em seu ponto médio, tomada com fita métrica.

Decorrido o período de resfriamento, as carcaças foram seccionadas ao meio com o auxílio de uma serra elétrica. Na meia carcaça esquerda realizou-se um corte transversal entre a $12^{\mathrm{a}}$ e $13^{\mathrm{a}}$ costela, expondo a secção transversal do músculo longissimus dorsi, permitindo determinar a área de olho de lombo (AOL) de duas formas: com auxílio de uma régua mensurando a largura máxima (A) e a profundidade máxima (B) para 
determinação da área (Figura 2.3), de acordo com a fórmula: $\mathrm{AOL}=(\mathrm{A} / 2+\mathrm{B} / 2) \pi$; e com o auxílio da Grade-UNESP.

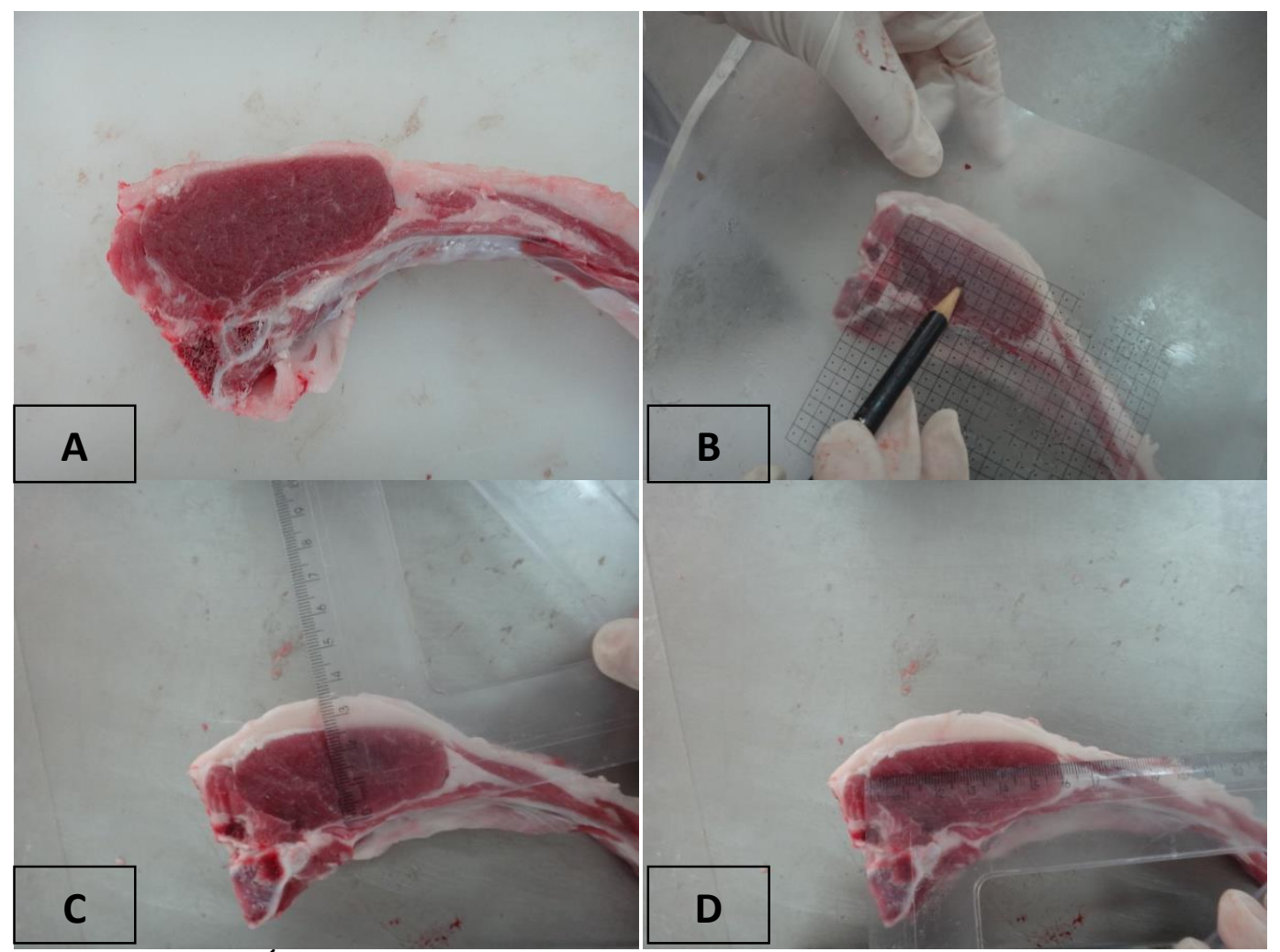

Figura 2.3: A- Área de Olho de Lombo (AOL); B- Grade Unesp; C- Profundidade máxima; D- Largura máxima.

Fonte: Arquivo pessoal

Realizou-se a medida de espessura de gordura subcutânea (EG) com o auxílio de um paquímetro (Figura 2.4).

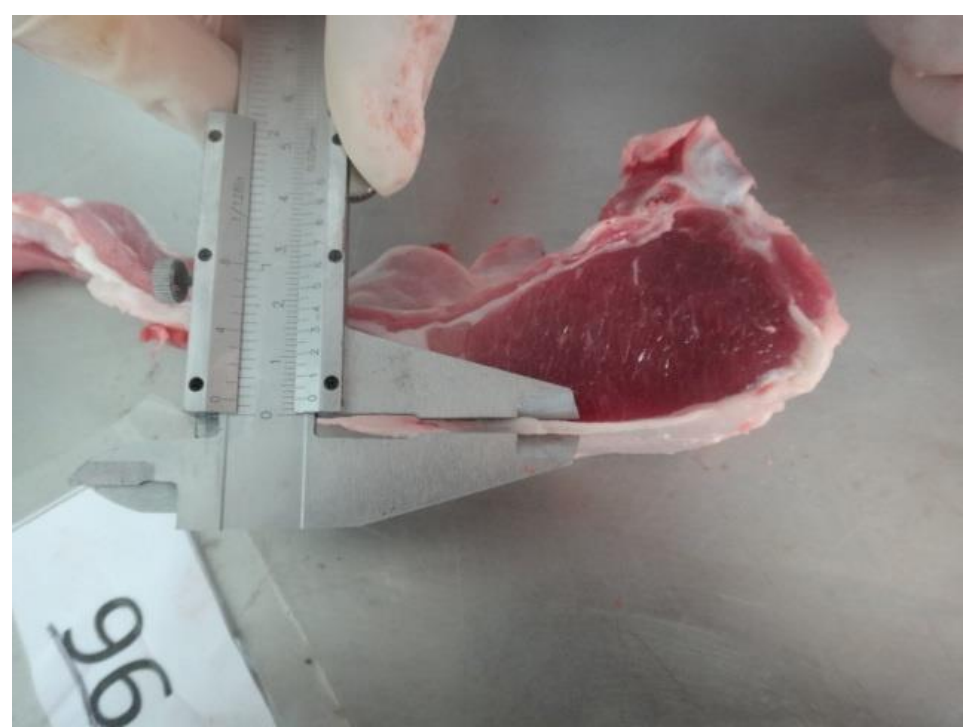

Figura 2.4: Medida da espessura da gordura subcutânea (EG). Fonte: Arquivo pessoal. 
Posteriormente, para a determinação dos principais cortes, a meia carcaça foi dividida em cinco cortes comerciais (Figura 2.5) a partir da metodologia descrita por Pereira Filho et al. (2008):

1. Perna: abrange a região do ílio, ísquio, púbis, vértebras sacrais, as duas primeiras vértebras coccígeas, fêmur, tíbia, e tarso.

2. Lombo: toda a região das vértebras lombares.

3. Costelas: incluem o esterno e todas as costelas e vértebras torácicas.

4. Paleta: região que compreende a escápula, úmero, rádio, ulna e carpo.

5. Pescoço: região correspondente às sete vértebras cervicais.
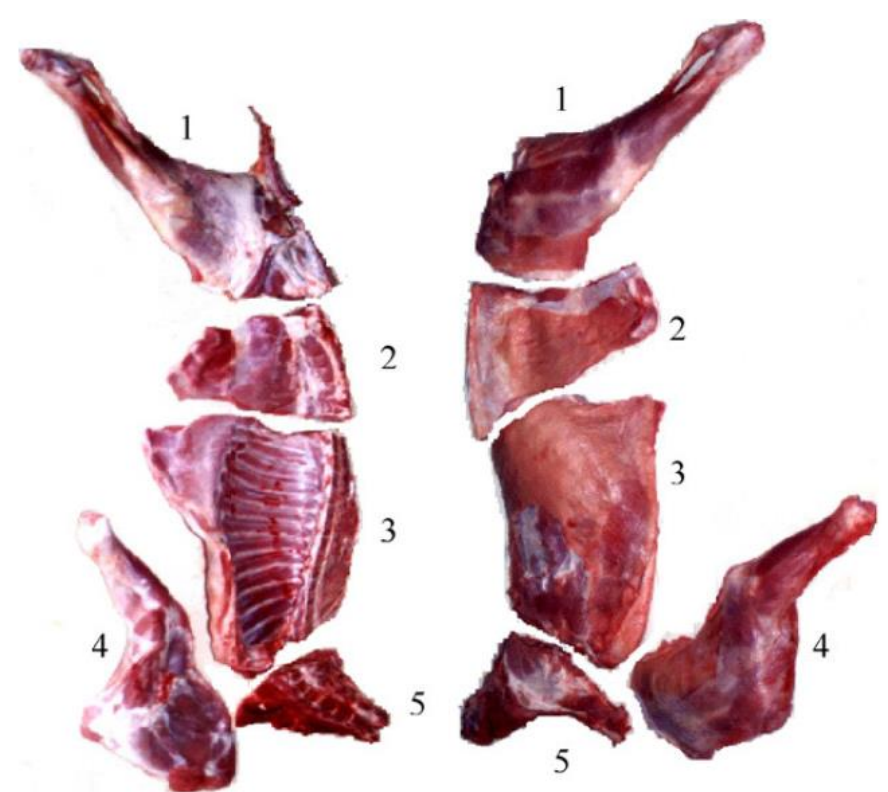

Figura 2.5: Metade esquerda da carcaça de caprinos dividida nos cinco principais cortes comerciais: 1. Perna, 2. Lombo, 3. Costelas, 4. Paleta e 5. Pescoço.

Fonte: Pereira Filho (2008).

Os dados foram analisados por meio do software Statistical Analysis System (SAS, 2012) pelo procedimento GLM. As médias foram obtidas pelo comando LSMEANS e comparadas pelo teste Tukey, com nível de 5\% de significância, para as variáveis significativas. Os dados foram submetidos a análise de covariância, obedecendo o delineamento inteiramente casualisado em esquema fatorial 3 x 2 (três grupos genéticos e dois tipos de parto). 


\section{RESULTADOS E DISCUSSÃO}

O grupo genético não influenciou as médias das variáveis, peso inicial (PI), peso final (PF), ganho de peso (GP), ganho médio diário (GMD) e eficiência alimentar (EA), os quais apresentaram médias de $15,84 \mathrm{~kg} ; 39,26 \mathrm{~kg} ; 23,41 \mathrm{~kg} ; 0,300 \mathrm{~kg} / \mathrm{dia}$ e 0,174, respectivamente, conforme Tabela 2.2.

Tabela 2.2. Média dos valores de peso inicial (PI), peso final (PF), ganho de peso (GP), ganho médio diário (GMD), consumo de matéria seca (CMS, \%PV), consumo de matéria seca em gramas por peso metabólico (CMS, g/PM), consumo de matériaseca em \%PM (CMS - \%PM), eficiência alimentar (EA), erro-padrão da média (EPM) e coeficiente de variação $(\mathrm{CV})$ de cordeiros de diferentes grupos genéticos e dois tipos de parto terminados em confinamento.

\begin{tabular}{lccccccc}
\hline \multirow{2}{*}{ Variáveis } & \multicolumn{3}{c}{ Grupo Genético $^{1}$} & \multicolumn{2}{c}{ Tipo de parto } & \multirow{2}{*}{ EPM } & \multirow{2}{*}{ CV } \\
\cline { 2 - 6 } & WD & Lacaune & Multimeat & Simples & Duplo & & \\
\hline PI (kg) & 15,80 & 15,77 & 15,96 & $17,59 \mathrm{a}$ & $13,16 \mathrm{~b}$ & 2,99 & 18,91 \\
PF (kg) & 38,75 & 39,2 & 39,83 & $41,63 \mathrm{a}$ & $35,58 \mathrm{~b}$ & 1,96 & 4,99 \\
GP (kg) & 22,95 & 23,43 & 23,85 & 24,04 & 22,42 & 1,96 & 8,38 \\
GMD (kg/dia) & 0,294 & 0,300 & 0,306 & 0,310 & 0,290 & 0,025 & 8,39 \\
CMS (\%PV) & $5,94 \mathrm{a}$ & $5,77 \mathrm{ab}$ & $5,44 \mathrm{~b}$ & $5,54 \mathrm{~b}$ & $5,98 \mathrm{a}$ & 3,0 & 5,0 \\
CMS (g/PM) & $135,57 \mathrm{a}$ & $131,33 \mathrm{a}$ & $124,38 \mathrm{~b}$ & 128,9 & 132,69 & 3,6 & 4,2 \\
CMS (\%PM) & $13,56 \mathrm{a}$ & $13,13 \mathrm{a}$ & $12,44 \mathrm{~b}$ & 13,27 & 12,89 & 2,4 & 8,0 \\
EA & 0,166 & 0,173 & 0,183 & $0,170 \mathrm{~b}$ & $0,190 \mathrm{a}$ & 3,1 & 7,5 \\
\hline
\end{tabular}

Médias seguidas por letras diferentes, dentro de cada linha, diferem pelo teste Tukey $(\mathrm{P}<0,05)$.

${ }^{1}$ Grupo genético: Santa Inês x White Dorper (WD), Santa Inês x Lacaune e Santa Inês x Multimeat

Avaliando o desempenho de cordeiros da raça Morada Nova, utilizando confinamento como sistema de terminação, com dieta contendo $60 \%$ de concentrado e $40 \%$ de volumoso, Zeoula (2002) observou ganho médio diário inferior ao encontrado neste trabalho, de 0,172 kg/dia. Este resultado pode ser explicado devido ao autor utilizar animal puro e com pouca habilidade para produção de carne.

Em estudo avaliando cordeiros $1 / 2$ Texel x $1 / 2$ Ideal, abatidos com peso médio de $30,9 \mathrm{~kg}$, Pires et al. (1999) obtiveram valor 3,28\% para CMS (\% PV) e 0,116 kg/dia de GMD, 
estes resultados foram inferiores ao encontrados neste estudo de 5,94\% e 0,300 kg/dia para CMS (\%PV) e GMD, respectivamente.

Foi observada diferença (Tabela 2.2) entre os tipos de parto para as variáveis PI, PF, CMS (\%PV) e EA, sendo que os animais provenientes de parto simples foram superiores aos de parto duplo para as variáveis PI, PF, e EA, demonstrando valores de 17,59 $\mathrm{kg}, 41,63 \mathrm{~kg}, 0,170$, respectivamente. Estes resultados ocorreram, provavelmente, devido aos animais de parto duplo terem iniciado o experimento com menor peso. Porém, os animais de parto duplo, apesar de apresentarem maior CMS (\%PV) quando comparado aos corderios de parto simples $(5,98 \%$ x 5,54\%) obtiveram o mesmo ganho de peso diário. Este resultado é muito relevante, pois indica que os animais de parto duplo podem apresentar desempenho satisfatório.

Não foi observada diferença para o ganho médio diário (GMD) entre os grupos genéticos e os tipos de parto. Em estudo realizado por Zundt et al. (2002), utilizando cordeiros machos, inteiros, "tricross" 1/2 Texel + 1/4 Bergamácia + 1/4 Coriedale, confinados com dieta contendo $16 \%$ de $\mathrm{PB}$, encontraram valores de $0,162 \mathrm{~kg} / \mathrm{dia}$, inferiores a este trabalho que foi em média de 0,300 kg/dia. Em trabalho avaliando cordeiros Texel x Ideal, provenientes de parto duplo e simples, confinados e abatidos aos $30 \mathrm{~kg}$ de PV, Carneiro et al. (2004) obtiveram menor CMS $(0,220 \mathrm{~g})$ quando comparado a este estudo.

Observa-se nesse estudo que os animais dos três grupos genéticos e os provenientes de parto simples e duplo apresentaram valores muito satisfatórios para ganho médio diário, esta característica é de grande importância para o desempenho animal e consequentemente promovendo maior rapidez para alcançar o peso ao abate.

Na Tabela 2.3 estão representados os dados referentes às características quantitativas da carcaça de cordeiros de diferentes grupos genéticos e tipos de parto. 
Tabela 2.3. Média dos valores de peso de carcaça quente (PCQ), peso de carcaça fria (PCF), rendimento de carcaça quente (RCQ), rendimento de carcaça fria (RCF) e porcentagem de perda de peso por resfriamento (PPR), índice de compacidade da carcaça (ICC) erro-padrão da média (EPM) e média do coeficiente de variação (CV) de cordeiros de diferentes grupos genéticos e dois tipos de parto terminados em confinamento

\begin{tabular}{lccccccc}
\hline \multirow{2}{*}{ Variáveis } & \multicolumn{3}{c}{ Grupo genético $^{1}$} & \multicolumn{2}{c}{ Tipo de Parto } & \multirow{2}{*}{ EPM } & \multirow{2}{*}{ CV } \\
\cline { 2 - 4 } & WD & Lacaune & Multimeat & Simples & Duplo & & \\
\hline PCQ (kg) & 17,66 & 17,03 & 18,26 & 18,01 & 17,22 & 1,16 & 6,58 \\
PCF (kg) & 17,13 & 16,53 & 17,69 & 16,93 & 15,00 & 1,14 & 6,64 \\
RCQ (\%) & 47,91 & 46,39 & 47,4 & 47,52 & 46,89 & 1,62 & 3,42 \\
RCF (\%) & 46,44 & 45,01 & 45,98 & 46,14 & 45,38 & 1,55 & 3,38 \\
PPR (\%) & 3,06 & 2,98 & 3,00 & 3,21 & 2,89 & 0,593 & 19,65 \\
ICC (kg/cm) & 0,63 & 0,63 & 0,66 & $0,67 \mathrm{a}$ & $0,59 \mathrm{~b}$ & 0,22 & 4,21 \\
\hline
\end{tabular}

Médias seguidas por letras diferentes, dentro de cada linha, diferem pelo teste Tukey $(\mathrm{P}<0,05)$.

${ }^{1}$ Grupo genético: Santa Inês x White Dorper (WD), Santa Inês x Lacaune e Santa Inês x Multimeat .

De acordo com os resultados da Tabela 2.3, não ocorreram diferenças entre os grupos genéticos em relação aos pesos e rendimentos de carcaça e PPR. Os valores médios para estas variáveis foram: 17,65 e 17,12 kg para PCQ e PCF, respectivamente; 47,23; 45,81; 3,01\% para RCQ, RCF, PPR, respectivamente.

Reis et al. (2001) utilizaram cordeiros machos Bergamácia x Corriedale, confinados, recebendo diferentes tipos de dieta, encontraram valores inferiores para PCQ $(14,66 \mathrm{~kg})$, PCF $(14,26 \mathrm{~kg})$ e PPR $(2,7 \%)$, comparados ao deste estudo de 17,65 kg, 17,08 kg e 3,01\%, para PCQ, PCF e PRR, respectivamente. Já Cartaxo et al. (2011) comparando animais SI puros e SI x Dorper, fornecendo dietas com diferentes níveis de energia, para PCQ $(17 \mathrm{~kg})$ e PCF $(16,03 \mathrm{~kg})$.

Em experimento utilizando cordeiros Turkish Merino em sistema de terminação em confinamento, abatidos aos $35 \mathrm{~kg}$, Eriz et al. (2009) obtiveram resultado superior ao deste trabalho para PCQ $(23,78 \mathrm{~kg})$, este resultado pode ser explicado devido ao tipo de volumoso fornecido (alfafa), o qual possui maior qualidade e maior quantidade de proteína.

Ribeiro (2010), avaliando cordeiros cruzados SI x Lacaune machos, não castrados, abatidos com $30 \mathrm{~kg}$, apresentaram valores inferiores para PCQ, PCF, PPR, de 14,36 $\mathrm{kg}, 14,08 \mathrm{~kg}$ e 2,03\%, respectivamente, quando comparados aos animais provenientes do cruzamento SI x Lacaune deste experimento. Porém os valores de rendimentos de carcaça quente e fria foram similares (47,54 e 46,59\%, respectivamente) aos do presente estudo. 
Os valores médios de pesos de carcaça quente e fria observados para os animais cruzados, assim como seus respectivos rendimentos, indicam que a raça Santa Inês, como raça materna, apresenta bom potencial para produção de carne, quando utilizada em cruzamentos com raças especializadas para produção de carne, como as utilizadas neste estudo.

Landim et al. (2007) utilizando cruzamento de Bergamácia x SI, em sistema de semi-confinamento, encontraram valores para PCQ de 10,65 kg, PCF de 10,31 kg e PPR de 3,0\%. Comparando este cruzamento com o utilizado neste trabalho (SI x Lacaune), observa-se superioridade nos PCQ e PCF (17,03 e 16,53 kg, respectivamente) e valor similar para perda ao resfriamento. Com este resultado nota-se que a raça Lacaune apresenta potencial para produção de carne em cruzamentos, ficando muito próxima a resultados utilizando raças especializadas para carne.

Os resultados obtidos nesse experimento diferem dos encontrados por Rech et al. (2014), que utilizando o cruzamento Texel x Corriedale, alimentados com diferentes fontes de proteína e relação concentrado:volumoso de 60:40, encontraram 16,4 e 15,90 kg, para PCQ e PCF, respectivamente.

Os cordeiros SI x WD apresentaram valores numéricos superiores para os rendimentos de carcaça quente $(47,91 \%)$ e fria $(46,44 \%)$ e perda por resfriamento $(3,06 \%)$. Estes resultados foram semelhantes aos encontrados por Cartaxo et al. (2009), para RCQ $(46,53 \%)$ e RCF $(45,65 \%)$, comparando o desempenho de cordeiros confinados Santa Inês puros e o cruzamento de SI x Dorper.

Os resultados obtidos por Araújo Filho et al. (2010) utilizando cordeiros Morada Nova, SI e mestiços SI x Dorper, terminados em confinamento, para RCQ (47,98\%) são semelhantes aos encontrados neste experimento para os mestiços de SI x White Dorper de $47,91 \%$. Porém o resultado para RCF $(46,99 \%)$ foi maior do que no presente estudo (46,44\%). Furusho-Garcia et al. (2000), trabalhando com animais mestiços Texel x Bergamácia e Texel x Santa Inês abatidos com pesos médios de 43,76 kg, não encontraram diferença no rendimento de carcaça quente entre os genótipos.

As perdas por resfriamento (PPR) das carcaças dos cordeiros entre grupos genéticos não foram significativas, o que confirma os resultados obtidos por Furusho-Garcia et al. (2000), trabalhando com animais mestiços Texel x Bergamácia e Texel x Santa Inês abatidos com pesos médios de 33,76 kg. Contudo, diferenças para PPR entre grupos genéticos foram encontradas por Osório et al. (2002) ao avaliarem cordeiros Border x Ideal e Border x Corriedale com 5,78 e $8,52 \%$, respectivamente. 
Sañudo \& Sierra (1986) afirmaram que o rendimento de carcaça fria varia entre 40 e $60 \%$ e que essa variação ocorre de acordo com a raça, os cruzamentos e com o sistema de produção, portanto, é maior em animais confinados e em produtos de cruzamentos quando se utilizam raças especializadas para produção de carne.

As variáveis RCQ, RCF e PPR, não apresentaram diferença entre os tipos de parto (Tabela 2.3), demonstrando valores médios de 47,19, 45,76 e 3,05\%, respectivamente. Houve diferença somente para a variável ICC (índice de compacidade da carcaça), em que os animais provenientes de parto simples apresentaram índice superior $(0,67)$ quando comparados aos de parto duplo $(0,59)$. Este resultado foi devido à superioridade do peso da carcaça fria dos animais de parto simples.

Diferente do encontrado neste estudo, Wommer et al. (2010), utilizando cordeiros machos, não-castrados, oriundos do cruzamento alternado de Texel e Ile de France, provenientes de parto simples ou duplo em confinamento, abatidos com $30 \mathrm{~kg}$, observaram menores pesos e rendimentos de carcaça quente e fria em animais provenientes de parto duplo, apresentando valores de 11,93 kg; 11,42 kg; 43,27\% e 41,43\%, respectivamente.

Pires et al. (2011) também não observou diferença $(\mathrm{P}>0,05)$ entre os tipos de parto ao utilizarem animais cruzados Ile de France x Texel, terminados em confinamento e abatidos com peso final de $30 \mathrm{~kg}$. No entanto, os autores obtiveram médias para RCQ e RCF inferiores à deste trabalho de 45,81 e 44,02\%, respectivamente.

Em experimento utilizando animais provenientes de partos simples e duplo, provenientes do cruzamento Texel x Ideal, abatidos aos $30 \mathrm{~kg}$ PV, Pires et al. (2006) observaram diferença $(\mathrm{P}<0,05)$ para as variáveis RCF e ICC. Demonstraram valores para os animais de parto simples de 14,92 e 15,50 kg, para PCQ e PCF, respectivamente; 48,66 e $2,75 \%$ para RCF e PPR, respectivamente e ICC de 0,26 kg/cm. Para os animais de parto duplo, obtiveram valores de 14,91 e 14,47 kg para PCQ e PCF, respectivamente; 47,51 e 2,98\% para RCF e PPR, respectivamente e ICC de 0,26 kg/cm. Esses resultados diferem dos encontrados nesse estudo, no qual o ICC foi superior $(0,67$ para parto simples e 0,59 para parto duplo) e o RCF foi inferior para animais de parto simples $(46,14 \%)$.

A PPR consiste na perda de umidade da carcaça na câmara fria e nas reações químicas do músculo durante o processo de resfriamento (Kirton, 1986). O índice de perda por resfriamento (PPR) não foi afetado pelo grupo genético e pelo tipo de parto. Maiores pesos ao abate determinam menores perdas no resfriamento, devido a este fato ser atribuído ao maior estágio de engorduramento das carcaças dos animais mais pesados, uma vez que a 
gordura é um protetor natural e evita que as carcaças fiquem expostas à câmara fria e percam água durante o resfriamento (Pires et al. 2011).

Não se observou diferença para o índice de compacidade da carcaça (ICC) entre os grupos genéticos. Este resultado difere do encontrado por Zundt et al. (2006), que ao trabalharem com cordeiros provenientes do cruzamento Bergamácia x Texel, terminados em sistema de confinamento, obtiveram valor médio de $0,24 \mathrm{~kg} / \mathrm{cm}$. Reis et al. (2001) encontraram menor índice para compacidade da carcaça $(0,21 \mathrm{~kg} / \mathrm{cm})$, em cordeiros mestiços Bergamácia x Corriedale em sistema de confinamento avaliando diferentes dietas. Cunha et al. (2000) observaram valor de $\operatorname{ICC}(0,25 \mathrm{~kg} / \mathrm{cm})$, em cordeiros Ile de France $\mathrm{x}$ Ideal terminados em confinamentos em diferentes idades. Resultado também inferior ao encontrado neste estudo foi observado por Zundt et al. (2003), que verificaram ICC de 0,27 kg/cm ao avaliarem cordeiros "tricross" (1/2 Texel + 1/4 Bergamácia $+1 / 4$ Corriedale $)$ terminados em sistema de confinamento.

Reis et al. (2001), utilizando animais mestiços "tricross", recebendo diferentes dietas contendo milho, obtiveram ICC menor $(0,21 \mathrm{~kg} / \mathrm{cm})$ do que o encontrado neste estudo. Outro estudo utilizando animais mestiços Ile de France x Corriedale, confinados, também demonstrou valores inferiores para ICC de $0,25 \mathrm{~kg} / \mathrm{cm}$ (Siqueira e Fernandes, 2000). O ICC encontrado neste trabalho apresenta valores expressivos para os diferentes grupos genéticos e os tipos de parto, indicando boa deposição de tecido muscular por unidade de comprimento, mesmo quando se trabalhando com raças indicadas para produção de leite como a Lacaune. Esses resultados são muito significativos quando comparados aos valores obtidos por outros trabalhos com grupos genéticos semelhantes.

Na tabela 2.4 encontram-se as mensurações realizadas no músculo Longissimus dorsi. Não houve efeito do grupo genético para os parâmetros quantitativos avaliados, sendo observados valores médios de $15,87 \mathrm{~cm}^{2}$ para a área de olho de lombo utilizando a grade quadriculada (AOLgd) e de $14,44 \mathrm{~cm}^{2}$ para a AOL calculada (AOLcal) e de 2,05 $\mathrm{mm}$ para a espessura de gordura subcutânea (EG). 
Tabela 2.4. Área de olho de lombo utilizando grade (AOLgd), área de olho de lombo calculado (AOLcal), espessura de gordura (EG), erro-padrão da média (EPM) e coeficiente de variação $(\mathrm{CV})$ de cordeiros de diferentes grupos genéticos e dois tipos de parto terminados em confinamento.

\begin{tabular}{lccccccc}
\hline \multirow{2}{*}{ Variáveis } & \multicolumn{3}{c}{ Tratamentos $^{1}$} & \multicolumn{2}{c}{ Tipo de parto } & \multirow{2}{*}{ EMP } & \multirow{2}{*}{ CV } \\
\cline { 2 - 4 } & WD & Lacaune & Multimeat & Simples & Duplo & & \\
\hline AOLgd $\left(\mathrm{cm}^{2}\right)$ & 16,41 & 15,36 & 15,84 & 16,59 & 14,81 & 4,37 & 13,84 \\
AOLcal $\left(\mathrm{cm}^{2}\right)$ & 14,82 & 14,22 & 14,29 & $15,06 \mathrm{a}$ & $13,50 \mathrm{~b}$ & 4,97 & 16,05 \\
EG $(\mathrm{mm})$ & 2,25 & 2,00 & 1,89 & 2,22 & 1,80 & 0,044 & 20,60 \\
\hline
\end{tabular}

Médias seguidas por letras diferentes, dentro de cadalinha, diferem pelo teste Tukey $(\mathrm{P}<0,05)$.

${ }^{1}$ Grupo genético: Santa Inês x White Dorper (WD), Santa Inês x Lacaune e Santa Inês x Multimeat

Como a AOL é um indicativo de desenvolvimento muscular no animal, pressupõe-se que o cruzamento de raça Santa Inês com raças especializadas para produção de carne melhore o índice de musculosidade em comparação aos animais da raça Santa Inês pura. O cruzamento das duas raças especializadas para corte (White Dorper e Multimeat) apresentaram valores semelhantes quando comparadas a raça Lacaune, sendo esta considerada, em muitos países, como raça dupla aptidão, com isto demonstra-se o potencial desta raça para a produção de carne, quando utilizada em cruzamentos industriais.

A mensuração da área de olho de lombo (AOL) é uma ótima ferramenta para estimar o desenvolvimento muscular por ser um dos indicativos da proporção de músculo da carcaça (Prado et al., 2004).

Nesse estudo, o resultado encontrado para AOL $\mathrm{cm}^{2}$ no cruzamento SI x WD, foi maior quando comparado ao estudo de Cartaxo et al. (2011), que verificaram valor de $12,42 \mathrm{~cm}^{2}$, utilizando diferentes grupos genéticos, recebendo dietas com diferentes energias e abatidos aos $30 \mathrm{~kg}$ de peso vivo.

Resultado inferior para AOLcm² foi encontrado por Fernandes et al. (2010), que avaliando sistemas de terminação de cordeiros Suffolk, abatidos com $32 \mathrm{~kg}$ PV, obtiveram valor de $11,27 \mathrm{~cm}^{2}$. Macedo et al. (2000), em estudo com cordeiros confinados Corriedale, Bergamácia x Corriedale e Hampshire Down x Corriedale submetidos a dietas com $18 \%$ de proteína, abatidos ao atingirem $32,4 \mathrm{~kg}$ de peso vivo, obtiveram média para AOL de $10,21 \mathrm{~cm}^{2}$, a qual foi inferior ao presente estudo.

A AOL do presente trabalho foi superior à obtida por Macedo (1998), que trabalhou com cordeiros Corriedale e mestiços Bergamácia x Corriedale e Hampshire Down x Corriedale, adotando a terminação em pastejo e confinamento, abatidos aos $33 \mathrm{~kg}$, ambas as dietas com $18 \%$ de PB, e obteve, valores de 9,03 10,21 cm², respectivamente. Em estudo para 
avaliar os efeitos da substituição do milho moído por resíduo de panificação (biscoito) em dietas para cordeiros cruzas Ile de France e Ideal, abatidos aos 35 kg, Garcia (1998) não encontrou diferença $(P>0,05)$ das substituições sobre a AOL, com média de $9,92 \mathrm{~cm}^{2}$.

A espessura de gordura encontrada por Cartaxo et al. (2011) foi superior para os animais SI x Dorper $(3,37 \mathrm{~mm})$ quando comparadas ao cruzamento SI x WD utilizado neste estudo (2,25 mm). A deposição da gordura em cordeiros, segundo Cezar \& Sousa (2007), ocorre do centro para as extremidades, portanto, quando é verificado um valor maior que 3 $\mathrm{mm}$, prediz que esta carcaça estará bem protegida durante o resfriamento. Sabe-se que este tecido é responsável por evitar perdas, protegendo as carcaças durante o resfriamento. Mahgoub et al. (2002) também afirmaram que a gordura funciona como um isolante térmico, atuando principalmente contra a desidratação, o endurecimento e o escurecimento de carne na carcaça durante o resfriamento.

Rech et al. (2014), utilizando animais inteiros, provenientes do cruzamento Texel x Corriedale, encontraram 4,9 mm de espessura de gordura subcutânea. Este valor foi superior ao encontrado no presente trabalho, isto deve-se ao fato da utilização de duas raças especializadas para corte e o tipo da dieta fornecida.

Observou-se diferença entre os tipos de parto para a variável AOLcal $\left(\mathrm{cm}^{2}\right)$ sendo observado valores de de 15,06 e $13,50 \mathrm{~cm}^{2}$, para parto simples e duplo, respectivamente. Animais provenientes de parto simples apresentaram maior área de olho de lombo, podendo ser explicado devido ao maior peso final destes animais, om que resultou em maior deposição de músculo na carcaça. Este resultado diferiu do encontrado por Pires et al. (2006), que avaliaram cruzamento de cordeiros Texel x Ideal, provenientes de parto simples e duplo, abatidos aos $30 \mathrm{~kg}$, e não encontraram diferença $(\mathrm{P}>0,05)$ para $\mathrm{AOL}$, apresentando valores de 12,95 e $12,59 \mathrm{~cm}^{2}$ para parto simples e duplo, respectivamente. Nesse caso, a similaridade da AOL entre os partos simples e duplos podem ter ocorrido devido aos animais serem abatidos com peso final igual.

Pires et al. (2011) utilizaram animais cruzados Ile de France x Texel, provenientes de partos duplo e simples, terminados em confinamento, abatidos com $29 \mathrm{~kg}$ de peso vivo e não observaram diferença entre os tipos de parto para as variáveis $\mathrm{AOL}\left(\mathrm{cm}^{2}\right)$ e EG, apresentando valores de 11,92 e 11,64 $\mathrm{cm}^{2}$, respectivamente para parto simples e duplo e $1,00 \mathrm{~cm}$ para espessura de gordura nos animais de parto simples e duplo. Estes resultados foram inferiores aos deste trabalho, possivelmente devido ao menor peso vivo final dos animais experimentais. 
Não foi observada diferença entre os tipos de parto para espessura de gordura (EG), sendo observados valores de 2,22 e $1,88 \mathrm{~mm}$, para parto simples e duplo, respectivamente. Este resultado difere do valor de 3,0 mm encontrado por Pires et al. (2006) para animais provenientes de parto duplo.

Os pesos e porcentagens dos principais cortes comerciais estão apresentados na Tabela 2.5. Observa-se que não houve influência dos grupos genéticos sobre os pesos (kg) dos cortes comerciais, tendo sido verificados valores médios de 0,$93 ; 1,41 ; 2,22 ; 1,02$ e 2,79 kg, para pescoço, paleta, costela, lombo e perna, respectivamente.

Tabela 2.5. Pesos médios e porcentagem dos cortes comerciais, erro-padrão da média (EPM) e média do coeficiente de variação $(\mathrm{CV})$ de cordeiros de diferentes grupos genéticos e dois tipos de parto terminados em confinamento.

\begin{tabular}{|c|c|c|c|c|c|c|c|}
\hline \multirow{2}{*}{ Variáveis } & \multicolumn{3}{|c|}{ Grupo genético $^{1}$} & \multicolumn{2}{|c|}{ Tipo de Parto } & \multirow{2}{*}{ EMP } & \multirow{2}{*}{$\mathrm{CV}$} \\
\hline & WD & Lacaune & Multimeat & Simples & Duplo & & \\
\hline \multicolumn{8}{|c|}{ Peso (kg) } \\
\hline Pescoço & 0,93 & 0,90 & 0,95 & 0,97 & 0,85 & 3,0 & 3,5 \\
\hline Paleta & 1,40 & 1,40 & 1,44 & $1,53 \mathrm{a}$ & $1,25 b$ & 3,5 & 4,3 \\
\hline Costela & 2,26 & 2,25 & 2,16 & 2,35 & 2,02 & 2,1 & 5,1 \\
\hline Lombo & 0,94 & 0,91 & 1,20 & $1,15 \mathrm{a}$ & $0,83 b$ & 0,5 & 4,2 \\
\hline Perna & 2,87 & 2,65 & 2,86 & $3,00 \mathrm{a}$ & $2,47 b$ & 1,2 & 3,1 \\
\hline Cortes Nobres $^{2}$ & 5,21 & 4,97 & 5,50 & $5,68 \mathrm{a}$ & $4,55 \mathrm{~b}$ & 3,1 & 4,0 \\
\hline \multicolumn{8}{|c|}{ Porcentagem $(\%)$} \\
\hline Pescoço & 11,01 & 11,08 & 11,07 & 10,74 & 11,54 & 4,0 & 3,7 \\
\hline Paleta & 16,68 & 17,35 & 16,78 & 16,97 & 16,84 & 4,1 & 2,4 \\
\hline Costela & 26,83 & 27,86 & 26,83 & 26,06 & 27,24 & 6,74 & 7,6 \\
\hline Lombo & 11,08 & 11,24 & 13,97 & 12,75 & 11,18 & 4,74 & 1,3 \\
\hline Perna & 34,10 & 32,64 & 33,13 & 33,40 & 33,19 & 2,1 & 6,8 \\
\hline Cortes Nobres $^{2}$ & 61,86 & 61,23 & 63,88 & 63,12 & 61,20 & 0,52 & 3,8 \\
\hline
\end{tabular}

Médias seguidas por letras diferentes, dentro de cada linha, diferem pelo teste Tukey $(\mathrm{P}<0,05)$.

${ }^{1}$ Grupo genético: Santa Inês x White Dorper (WD), Santa Inês x Lacaune e Santa Inês x Multimeat .

${ }^{2}$ Cortes Nobres $=$ perna, paleta e lombo.

A participação proporcional dos cortes em relação ao peso da carcaça fria apresentou comportamento semelhante ao observado para peso absoluto, uma vez que nenhum dos cortes sofreu influência do grupo genético, sendo que esses valores estão adequados e semelhantes aos encontrados na literatura para raças especializadas em produção de carne. Agrupando os cortes, considerando a sua proporcionalidade em relação ao peso da carcaça fria, obteve-se a seguinte ordem: perna $>$ costela $>$ paleta $>$ lombo $>$ pescoço. 
Os resultados encontrados foram semelhantes aos encontrados por Oliveira et al. (2002), que trabalharam com cordeiros SI e Bergamácia e não encontraram diferenças $(\mathrm{P}>0,05)$ nos cortes comerciais estudados entre os grupos genéticos. Cartaxo et al. (2002) avaliando cruzamentos de cordeiros Dorper x SI, terminados em confinamento e abatidos com $30 \mathrm{~kg}$ de peso vivo, encontraram pesos menores para perna $(2,48 \mathrm{~kg})$, paleta $(1,35 \mathrm{~kg})$, pescoço $(0,55 \mathrm{~kg})$ e costela $(2,20 \mathrm{~kg})$. Os resultados obtidos no presente estudo corroboram para demonstrar que o cruzamento industrial é uma ferramenta interessante quando se visa à deposição de carne, principalmente nos cortes nobres, , permitindo a obtenção de pesos mais elevados ao abate e consequentemente maior valor agregado ao produto.

Os valores dos cortes comerciais encontrados por Araújo Filho et al. (2010) trabalhando com animais mestiços SI x Dorper, confinados e submetidos a dietas com diferentes níveis de energia, abatidos aos $30,5 \mathrm{~kg}$, diferiram do presente estudo, apresentando valores de $0,48,1,19,1,80,2,20 \mathrm{~kg}$, para pescoço, paleta, costela e perna, respectivamente. Cartaxo et al., (2009), utilizando cordeiros das raças SI e cruzamento SI x Dorper, abatidos aos $30 \mathrm{~kg}$ de peso vivo, não encontraram diferença significativa para peso da perna. De forma semelhante, Furusho-Garcia et al. (2003) também não verificaram diferença significativa $(\mathrm{P}>0,05)$ entre os cordeiros da raça SI, mestiços Texel x SI para peso da perna.

Em estudo utilizando animais mestiços Suffolk, alimentados com diferentes níveis de energia na dieta e abatidos aos $31 \mathrm{~kg}$, apresentaram peso de paleta, perna, lombo e pescoço de 1,$40 ; 2,54 ; 0,78$ e $0,65 \mathrm{~kg}$, respectivamente, os quais foram inferiores aos encontrados no presente trabalho. Os rendimentos da perna $(34,39 \%)$ e da paleta $(20,38 \%)$ foram superiores e para lombo $(10,47 \%)$ e pescoço $(8,70 \%)$, inferiores a este estudo (Garcia et al., 2003).

Siqueira et al. (2001), avaliando cordeiros machos mestiços Ile de France x Corriedale, terminados em confinamento e abatidos com média de $40 \mathrm{~kg}$, encontraram valores para os cortes comerciais de pescoço $(0,61 \mathrm{~kg})$, costela $(0,83 \mathrm{~kg})$, paleta $(1,7 \mathrm{~kg})$, lombo $(0,79$ $\mathrm{kg}$ ) e perna $(2,71 \mathrm{~kg})$. Estes resultados foram inferiores ao presente estudo para os pesos de costela $(2,22 \mathrm{~kg})$, lombo $(1,02 \mathrm{~kg})$, perna $(2,79 \mathrm{~kg})$ e pescoço $(0,93 \mathrm{~kg})$ e superiores para paleta $(1,41 \mathrm{~kg})$.

Furusho-Garcia et al. (2003) comparando animais puros Santa Inês e cruzamentos Texel x SI e Texel x Bergamácia, avaliando dietas contendo casca de café, abatidos aos $31,5 \mathrm{~kg}$ de peso vivo encontraram valores de 0,$99 ; 2,15 ; 1,78 ; 3,21$ e $0,83 \mathrm{~kg}$ para pescoço, costela, paleta, perna e lombo, respectivamente. Os valores de pescoço, costela 
e lombo estão de acordo com os encontrados neste experimento, enquanto os pesos de perna e paleta foram superiores.

Macedo et al. (2000), estudando cordeiros Corriedale, Bergamácia x Corriedale e Hampshire Down x Corriedale em confinamento, submetidos à dieta com 18\% de proteína, abatidos aos $30 \mathrm{~kg}$ de PV, encontraram valores de 32,91\% para rendimento de perna, 18,86\% para paleta, 9,88\% para lombo e 6,0\% para pescoço, estes resultados foram superiores aos do presente estudo para o rendimento da paleta $(16,94 \%)$ e inferiores para os rendimentos de perna $(33,29 \%)$, lombo $(12,1 \%)$ e pescoço $(11.05 \%)$.

Dos cortes cárneos, a perna apresentou maior média para os grupos genéticos $(2,79 \mathrm{~kg})$ quando comparado aos demais cortes. Os resultados concordam com FurushoGarcia et al. (2004), que relatam a paleta e a perna representam mais de 50\% da carcaça, sendo estes cortes os que melhor predizem o conteúdo total dos tecidos da carcaça.

Resultados semelhantes ao deste estudo foram reproduzidos por Cardoso et al. (2013) utilizando o cruzamento industrial Texel x SI, terminados em sistema de confinamento, abatidos com $30 \mathrm{~kg}$ de peso vivo, reportam valores para os cortes comerciais de 2,$91 ; 0,72 ; 1,51 ; 2,59$ e $0,91 \mathrm{~kg}$, para perna, lombo, paleta, costela e pescoço, respectivamente.

Houve influência do tipo de parto sobre os pesos dos cortes comerciais, em que os animais provenientes de parto simples apresentaram valores superiores para o peso da paleta $(1,53 \mathrm{~kg})$, lombo $(1,15 \mathrm{~kg})$, perna $(3,0 \mathrm{~kg})$ e cortes nobres $(5,68 \mathrm{~kg})$. Os valores superiores para os animais de parto simples eram esperados devido ao maior peso vivo ao abate e, consequentemente, ao maior peso de carcaça fria. Vale ressaltar que estes cortes são de fundamental importância para o frigorífico, por apresentarem maior valor comercial.

Não ocorreu diferença do tipo de parto em relação aos pesos do pescoço e costela, e também no peso relativo $(\%)$ dos cortes comerciais na carcaça sendo encontrados valores médios de 0,91 e 2,19 $\mathrm{kg}$ para pescoço e costela, respectivamente; 11,14; 16,91; 26,65; 11,97 e 33,3\%, para os pesos relativos do pescoço, paleta, costela, lombo e perna, respectivamente.

Estes resultados estão de acordo com o encontrado por Pires et al. (2006) que trabalhando com animais provenientes de parto simples e duplo, cruzados Texel x Ideal, abatidos com $30 \mathrm{~kg}$ PV, verificaram valores de 19,61; 38,28 e 7,90\%, para paleta, costela e pescoço, respectivamente, em animais de parto simples; e 19,02; 39,71 e 7,48\%, para paleta, costela e pescoço, respectivamente, em animais de parto duplo. 
Resultados encontrados por Pires et al. (2011), ao avaliarem cordeiros machos não-castrados, provenientes de partos simples e duplo, estão de acordo com este trabalho, pois não observaram diferença $(\mathrm{P}>0,05)$ para os valores percentuais da perna, paleta, costela e pescoço apresentando médias de 34,0; 18,81; 38,24 e 8,96\%, respectivamente. 


\section{CONCLUSÕES}

Independente da raça paterna utilizada, as matrizes Santa Inês demonstraram resultados satisfatórios para o desempenho e de características quantitativas da carcaça, podendo esta ser utilizada como base materna no cruzamento industrial.

Contrariamente ao que se espera, observou-se similaridade no desempenho e nas características quantitativas da carcaça do parto gemelar quando comparado ao parto simples, podendo este ser utilizado em sistema de terminação em confinamento. 


\section{REFERÊNCIAS BIBLIOGRÁFICAS}

AZZARINI, M. Produção de carne ovina. $1^{a}$ Jornada Técnica de Produção Ovina no RS. Bagé-RS-Brasil. P. 49-63. 1979

CARDOSO, M.T.M.; LANDIM, A.V.; LOUVANDINI, H. McMANUS, C. Performance and carcass quality in three genetic groups of sheep in Brazil. Revista Brasileira de Zootecnia, v.42, n.10, p.734-742, 2013.

CARTAXO, F.Q.; CEZAR, M.F.; SOUSA, W.H.; NETO, S.G.; FILHO, J.M.P.; CUNHA, M.G.G. Características quantitativas da carcaça de cordeiros terminados em confinamento e abatidos em diferentes condições corporais. Revista Brasileira de Zootecnia, v.38, n.4, p.697-704, 2009.

CARTAXO, F.Q.; SOUSA, W.H.; COSTA, R.G.; CEZAR, M.F.; FILHO, J.M.P. Características quantitativas da carcaça de cordeiros de diferentes genótipos submetidos a duas dietas. Revista Brasileira de Zootecnia, v.40, n.10, p.2220-2227, 2011.

CEZAR, M.F.; SOUSA, W.H. Carcaças ovinas e caprinas: obtençãoavaliaçãoclassificação. Uberaba: Agropecuária Tropical, 2007. 232p.

CUNHA, E.A.; SANTOS, L.E.; BUENO, M.S. et al. Utilização de carneiros de raças de corte para obtenção de cordeiros precoces para abate em plantéis produtores de lã. Revista Brasileira de Zootecnia, v.29, n.1, p.243-252, 2000.

EKIZ, B.; YILMAZ, A.; OZCAN,M.; KAPTAN, C.; HONAGLU,H. Carcass measurements and meat quality of Turkish Merino, Ramlic, Kivircik, Chios and Imroz lambs raised under an intensive production system. Journal of Animal Science, v,82, n.1, p.64-70, 2009.

FERNANDES, M.A.M.; MONTEIRO, A.L.G.; ESPIRITO, C.H.; POLI, C.; BARROS, C.S.; ALMEIDA, R. Composição tecidual da carcaça e perfil de ácidos graxos da carne de cordeiros terminados a pasto ou em confinamento. Revista Brasileira de Zootecnia, v.39, n.7, p.1600-1609, 2010.

FIGUEIRÓ, P.R.P. Efeito do cruzamento da raça Hampshire Down e Romney Marsh na produção de cordeiros para abate. Revista do Centro de Ciências Rurais, v.9, p. 421-428, 1979.

FURUSHO-GARCIA, I. F.; PEREZ, J. R. O; BONAGURIO, S.; LIMA, A. L.; QUINTÃO, F. A. Estudos dos cortes de carcaça de cordeiros Santa Inês puros e cruzas Santa Inês com Texel, 
Ile de France e Bergamácia. Revista Brasileira de Zootecnia, Viçosa, v. 33, p. 453-462, 2004.

FURUSHO-GARCIA, I.F.; OLALQUIAGA, J.R.; TEIXEIRA, J.C. Componentes de Carcaça e Composição de Alguns Cortes de Cordeiros Texel x Bergamácia, Texel x Santa Inês e Santa Inês Puros, Terminados em Confinamento, com Casca de Café como Parte da Dieta. Revista Brasileira de Zootecnia, v.32, n.6, p.1999-2006, 2003 (Suplemento).

FURUSHO-GARCIA, I.F.F.; PEREZ, J.R.O.; OLIVEIRA, M.V. Características de carcaça de cordeiros Texel x Bergamácia, Texel x Santa Inês e Santa Inês Puros, terminados em confinamento, com casa de café como parte da dieta. Revista Brasileira de Zootecnia, v.29, n.1, p.253-260, 2000

PATRICK FRANCIS. Boorola gene revival in new composite breed package. Australian Farm Journal, 2008.

GARCIA, C.A. Avaliação do resíduo de panificação "biscoito" na alimentação de ovinos e nas características quantitativas e qualitativas da carcaça. Jaboticabal: Universidade Estadual Paulista, 1998. 79p. Dissertação (Mestrado em Zootecnia) - Universidade Estadual Paulista, 1998.

GARCIA, C.A.; MONTEIRO, A.L.G.; COSTA, C.; NERES, M.A.; ROSA, G.J.M. Medidas Objetivas e Composição Tecidual da Carcaça de Cordeiros Alimentados com Diferentes Níveis de Energia em Creep Feeding. Revista Brasileira de Zootecnia, v.32, n.6, p.13801390, 2003.

KIRTON, A.H. Animal Industries Workshop Lincoln College, Technical Handbook (lamb growth - carcass composition). 2.ed. Canterbury: Lincoln College, 1986. p.25-31.

LANDIM, A.V.; MARIANTE, A.S.; McMANUS, C.; GUGEL, R.; PAIVA, S.R. Características quantitativas da carcaça, medidas morfométricas e suas correlações em diferentes genótipos de ovinos. Ciência Animal Brasileira, v. 8, n. 4, p. 665-676, 2007.

MACEDO, F.A.F. Desempenho e características de carcaças de cordeiros Corriedale e mestiços Bergamácia x Corriedale e Hampshire Down x Corriedale, terminados em pastagem e confinamento. Botucatu/ SP: UNESP, 1998.72 p.Tese (Doutorado em Zootecnia)Universidade Estadual Paulista, 1998.

MACEDO, F.A.F.; SIQUEIRA, E.R.; MARTINS, E.N. et al. Qualidade de carcaças de cordeiros Corriedale puros e mestiços terminados em pastagem e confinamento. Revista Brasileira de Zootecnia, v.29, n.5, p.1520-1527, 2000

MAHGOUB, O.; LU, C.D. Influence of various levels of metabolisable energy on chemical composition of whole carcass and non-carcass portion of goats and sheep. South African

OLIVEIRA, M.V.M.; PÉREZ, J.R.O.; ALVES, E.L. et al. Rendimento de carcaça, mensurações e peso de cortes comerciais de cordeiros Santa Inês e Bergamácia alimentados com dejetos de suínos em confinamento. Revista Brasileira de Zootecnia, v.31, n.3, p.14511458, 2002 (suplemento). 
PEREIRA FILHO, J.M.; RESENDE, K.T.; TEIXEIRA, I.A.M.A. et al. Características da carcaça e alometria dos tecidos de cabritos F1 Boer $\times$ Saanen. Revista Brasileira de Zootecnia, v.37, n.5, p.905-912. 2008.

PIRES, C.C.; CARNEIRO, R.M.; MULLER, L.; SOUZA, J.H.S.; CARDOSO, A.R.; NETO, D.P. Avaliação da carcaça e componentes do peso vivo, de cordeiros de parto simples desmamados, parto simples não desmamados e de parto duplo desmamados. Revista Brasileira de Agrociência, v. 12, n. 1, p. 93-97, 2006

PIRES, C.C.; MULLER, L.; TONETTO, C.J.; CARVALHO, S. Influência do tipo de parto e do sexo no desempenho e nas características da carcaça de cordeiros cruza lle de France $\mathrm{x}$ Texel. Revista Ceres, v. 58, n.4, p. 432-437, 2011.

PIRES, C.C.; SILVA, L.F.; SCHLICK, F.E. et al. Cria e terminação de cordeiros confinados. Ciência Rural, v.30, n.5, p.875-880, 2000.

PRADO, C.S.; PÁDUA, J.T.; CORREA, M.P.C. et al. Comparação de diferentes métodos de avaliação da área de olho de lombo e cobertura de gordura em bovinos de corte. Ciência Animal Brasileira v.5, n.3, p.141-149, 2004.

RECH, C.L.S.; RECH, J.L.; FISHER, V.; WIEGAND, M.M.; MOREIRA, H.L.M. Body development, carcass, and meat quality of confined lambs fed increasing levels of whole rice meal. Tropical Animal Health and Production, v. 46, n.1, p. 191-195, 2014.

REIS, W.; JOBIM, C.C.; MACEDO, F.A.F. et al. Desempenho de cordeiros terminados em confinamento, consumindo silagens de grãos de milho em diferentes formas. Revista Brasileira de Zootecnia, v.30, n.2, p.525-532, 2001.

SAÑUDO, C.; SIERRA, I. Calidad de la canal en la especie ovina. Revista Ovis, v.1, p.127153, 1986.

SIQUEIRA, E.R.; FERNANDES, S. Efeito do Genótipo sobre as Medidas Objetivas e Subjetivas da Carcaça de Cordeiros Terminados em Confinamento. Revista Brasileira de Zootecnia, v.29, n.1, p.306-311, 2000.

SIQUEIRA, E.R.; SIMOES, C.D.; FERNANDES, S. Efeito do Sexo e do Peso ao Abate sobre a Produção de Carne de Cordeiro. Morfometria da Carcaça, Pesos dos Cortes, Composição Tecidual e Componentes Não Constituintes da Carcaça. Revista Brasileira de Zootecnia, v.30, n.4, p.1299-1307, 2001.

WOMMER, T.P.; VENTURINI, R.S.; BOLZAN, A.M.S. rendimento de carcaça de cordeiros confinados oriundos de parto simples ou duplo. In: III SEMINÁRIO: SISTEMAS DE PRODUÇÃO AGROPECUÁRIA, 2010.

ZEOULA, N.M.B.L. Influência da alimentação nas características quantitativas da carcaça e qualitativas da carne de cordeiros Morada Nova. Jaboticabal: Universidade de São Paulo. 2002 
ZUNDT, M.; MACEDO, F.A.F.; MARTINS, E.N. et al. Características de carcaça de cordeiros terminados em confinamento, com dietas contendo diferentes níveis protéicos. Ciência Rural, v.33, n.3, p. 565-571, 2003.

ZUNDT, M.; MACEDO, F.A.F.; MARTINS, E.N.; MEXIA, A.A.; YAMAMOTO, S.M. Desempenho de Cordeiros Alimentados com Diferentes Níveis Protéicos. Revista Brasileira de Zootecnia, v.31, n.3, p.1307-1314, 2002.

ZUNDT,M.; MACEDO, F.A.F.; ASTOLPHI, J.L.L.; MEXIA, A.A.; SAKAGUTI, E.S. Desempenho e características de carcaça de cordeiros Santa Inês confinados, filhos de ovelhas submetidas à suplementação alimentar durante a gestação. Revista Brasileira de Zootecnia, v.35, n.3, p.928-935, 2006. 


\section{CAPÍTULO 3}

CARACTERÍSTICAS QUALITATIVAS DA CARCAÇA E DA CARNE DE CORDEIROS DE DIFERENTES GRUPOS GENÉTICOS 


\section{RESUMO}

Objetivou-se com este trabalho determinar a influência do cruzamento industrial e o tipo de parto sobre os parâmetros qualitativos da carcaça e da qualidade da carne de cordeiros terminados em confinamento.. Utilizou-se 24 cordeiros, machos, não castrados, de diferentes grupos genéticos formados pelo cruzamento das raças Santa Inês (SI) x White Dorper (WD), SI $x$ Lacaune, SI x Multimeat. Os animais, distribuídos em delineamento inteiramente casualizado em arranjo fatorial 3 X 2 (3 grupos genéticos e 2 tipos de parto), foram confinados em baias individuais e alimentados com ração composta de silagem de milho e concentrado (25:75). Os animais foram abatidos ao atingirem peso corporal médio de 39,26 $\mathrm{kg}$. Após 45 minutos do abate, determinou-se no músculo Longissimus dorsi, o pH e a temperatura das carcaças. Em seguida, as carcaças foram submetidas ao resfriamento em câmara fria por $24 \mathrm{~h}$ a $5^{\circ} \mathrm{C}$ e então se aferiu novamente o $\mathrm{pH}$ e a temperatura. Para avaliação das características qualitativas foram retiradas porções do músculo Longissimus dorsi de cada carcaça esquerda, determinando-se, a cor; as perdas por cocção (PPC) e a força de cisalhamento (FC). A perna foi dissecada em músculo, osso e gordura, calculando-se as relações músculo:osso e músculo:gordura. Entre os grupos genéticos, houve diferença significativa para a variável cor sendo observado maior valor de luminosidade $\left(\mathrm{L}^{*}\right)$ na carne de cordeiros do grupo genético SI x Multimeat. Comparando os dois tipos de parto, observou-se que os animais provenientes de parto simples apresentaram maior intensidade de vermelho $\left(b^{*}\right)$. O cruzamento de fêmeas da raça Santa Inês com machos das raças Dorper, Lacaune ou Multimeat não alteram as características qualitativas da carcaça e da qualidade da carne adequadas, sendo estas raças indicadas para programas de cruzamento industrial para produção de cordeiros confinados.

Palavras-chave: cor, cordeiros, cruzamento industrial, Multimeat, maciez, $\mathrm{pH}$. 


\section{ABSTRACT \\ QUALITATIVE CHARACTERISTICS OF CARCASS AND MEAT OF LAMBS FROM DIFFERENT GENETIC GROUPS}

The objective of this work was to determine the influence of crossbreeding and the type of parturition on the qualitative parameters of carcass and meat quality the lambs finished in feedlot. For the experiment, were used 24 lambs, male, uncastrated, of three different genetic groups and two types of parturition, single and double, distributed in a completely randomized design in $2 \times 3$ factorial arrangement (three genetic groups $\mathrm{x}$ two types of parturition), obtaining the treatments: 1) Santa Inês (SI) x White Dorper (WD), 2) Santa Inês $x$ Lacaune (LAC) and 3) Santa Inês x Multimeat (MULT). The animals started the experiment with average body weight of $15 \mathrm{~kg}$ and were allocated in individual pens getting diet based on corn silage and concentrate the soybean meal corn and mineral core, being the roughage: concentrate 25:75. The animals were slaughtered when they reached average weight of 39.26 $\mathrm{kg}$. After 45 minutes slaughter was determined in Longissimus dorsi muscle the $\mathrm{pH}$ and the temperature of carcasses. Next, the carcass were subjected to cooling in a cold room for 24 hours at $5{ }^{\circ} \mathrm{C}$ and then again check $\mathrm{pH}(24 \mathrm{~h})$ temperature. For evaluation of the qualitative characteristics were removed portions the Longissimus dorsi muscle of each left housing determining the color: lightness $(\mathrm{L} *)$, redness $(\mathrm{a} *)$ and yellow $(\mathrm{b} *)$; the cooking losses $(\mathrm{CL})$ and shear force (SF). The leg was dissected in muscle, bone and fat, calculating the relations of muscle: bone and muscle: fat. There was no difference in the influence of the interaction $(\mathrm{P}>0.05)$ between the different genetic groups and types of birth on the variables studied in this experiment, as well as there was no statistical difference. Among the genetic groups was no significant difference for the variable $\mathrm{L} *$ color, with higher luminosity in meat for the SI $\mathrm{x}$ Multimeat cross (41.82). Comparing the two types of parturion, there was difference in the color $b *$, where the animals from simple birth had higher red intensity (4.95). The crossing using females Santa Inês and White Dorper, Lacaune and Multimeat, in industrial crossbred, showed excellent qualitative characteristics of carcass and meat quality, which are listed in industrial crossbreeding for feedlot finished.

Key-words: color, industrial crossbreeding, lambs, Multimeat, $\mathrm{pH}$, softness 


\section{INTRODUÇÃO}

A produção de ovinos de corte está em plena expansão e crescimento em todo território brasileiro. No entanto, Pires et al. (2000) ressaltaram que, para a carne ovina ter condições de competir com a de outras espécies, tais como aves, suínos e bovinos, o produtor deve colocar no mercado carne de animais jovens (cordeiros), criados de maneira adequada para obtenção de carcaças de qualidade, pois o consumidor está cada vez mais exigente e busca produtos mais saborosos e saudáveis.

Portanto, é de suma importância conhecer os parâmetros de qualidade da carne, como $\mathrm{pH}$, cor, perdas de água por cocção e maciez, para produzir e processar adequadamente esses produtos, buscando obter alta qualidade da carne e proporcionar maior competitividade entre as demais fontes de origem animal (Pinheiro et al., 2009).

Carvalho et al. (1980) também ressaltaram que o estudo dos aspectos qualitativos das carcaças ovinas é de suma importância, haja vista as peculiaridades dos sistemas de produção e dos genótipos utilizados. O uso de melhor alimentação, sistema de terminação e cruzamentos industriais podem causar sensíveis modificações nas características de grande importância econômica.

De acordo com Sainz (1996), o peso é um fator importante na predição do rendimento da carcaça. No entanto, pode ocorrer do peso não representar uma estimativa adequada de sua composição, já que com o aumento de peso da carcaça seu conteúdo de gordura também aumenta, diminuindo a proporção de músculo e, consequentemente, diminuindo o rendimento de carne magra (como proporção do peso da carcaça). Diante desse contexto, o autor afirmou que as proporções dos componentes da carcaça mais importantes: osso, músculo e gordura, são um dos fatores de maior relevância referente às características quantitativas da carcaça.

O objetivo deste trabalho foi avaliar as características qualitativas da carcaça e da carne de cordeiros de três diferentes grupos genéticos terminados em sistema de confinamento. 


\section{MATERIAL E MÉTODOS}

O experimento foi realizado no Centro de Manejo de Ovinos (CMO), localizado na Fazenda Água Limpa (FAL), de propriedade da Universidade de Brasília (UnB), situada junto à cidade de Brasília-DF. O clima da região é do tipo AW pela classificação de Koppen, com temperatura medial anual de $23{ }^{\circ} \mathrm{C}$, tendo $16{ }^{\circ} \mathrm{C}$ e $34{ }^{\circ} \mathrm{C}$ como mínima e máxima absoluta, respectivamente. A precipitação anual é de $1.300 \mathrm{~mm}$ e a média anual de umidade relativa do ar é de $66 \%$.

Foram utilizados 24 cordeiros machos inteiros de três diferentes grupos genéticos (1. Santa Inês x White Dorper, 2. Santa Inês x Lacaune e 3. Santa Inês x Multimeat) e dois tipos de parto (simples ou duplo), distribuídos em delineamento inteiramente casualizado (DIC), em arranjo fatorial $3 \times 2$ (três grupos genéticos e dois tipos de partoOs animais iniciaram o experimento com o peso médio de $15 \mathrm{Kg}$ e idade média de 70 dias, sendo vermifugados antes do início do experimento.

Os cordeiros foram mantidos em sistema de confinamento, distribuídos em baias individuais providas de comedouro e bebedouro, alocadas em um prédio de alvenaria, com cobertura metálica e contendo cortinas móveis para evitar incidência de chuvas e ventos fortes.

O período experimental foi de 23 de outubro a 29 de janeiro de 2013 , com duração de 98 dias, sendo 20 dias de adaptação à dieta e às condições de instalações e 78 dias experimentais, divididos em três períodos de 26 dias. Os animais foram pesados no início do experimento e no final de cada período experimental, a fim de monitorar o desempenho dos cordeiros e o cálculo da quantidade de alimento a ser fornecida.

Os animais experimentais foram alimentados com ração composta de silagem de milho e concentrado contendo farelo de milho (68,2\%), farelo de soja $(27,8 \%)$ e núcleo mineral (4\%), sendo que a relação volumoso:concentrado foi de 25:75. A ração total foi formulada de acordo com recomendações do AFRC (1998), apresentando média de 16\% de Proteína Bruta (PB) e 75\% de Nutrientes Digestíveis Totais (NDT), visando atender as 
exigências nutricionais em proteína e energia metabolizável de cordeiros em crescimento e proporcionar ganhos de peso em torno de $250 \mathrm{~g} / \mathrm{dia}$.

A ração foi fornecida duas vezes ao dia (4\% de MS em relação ao peso vivo), às 9:00 e 17:00 horas e água a vontade. As sobras foram retiradas diariamente antes do fornecimento da ração na parte da manhã e pesadas, visando o monitoramento da quantidade consumida, proporcionando em torno de $15 \%$ de sobras.

Os cordeiros foram abatidos ao término do período experimental, com peso vivo médio de 39,26 kg, após jejum de aproximadamente 16 horas de dieta sólida, em um frigorífico comercial localizado em Samambaia/DF que possui fiscalização do Departamento de Inspeção de Produtos de Origem Vegetal e Animal (DIPOVA/MAPA), seguindo as normas de abate humanitário. A insensibilização foi realizada por meio de eletronarcose, seguida pela sangria, seccionando as veias jugulares e as artérias carótidas. Após a esfola, evisceração e retirada das extremidades (patas) e cabeça, realizou-se a mensuração do pH (pH 45') das carcaças quentes. Logo após, as carcaças foram submetidas ao resfriamento em câmara fria por $24 \mathrm{~h}$ a $5^{\circ} \mathrm{C}$ e então determinou-se novamente o $\mathrm{pH}(\mathrm{pH} 24 \mathrm{~h})$ e a temperatura final das carcaças, sendo que essas mensurações foram realizadas sempre no músculo Longissimus dorsi, com o auxílio de um equipamento digital apropriado para medir o pH e a temperatura de carne, com eletrodo e termômetro de penetração (Figura 3.1).

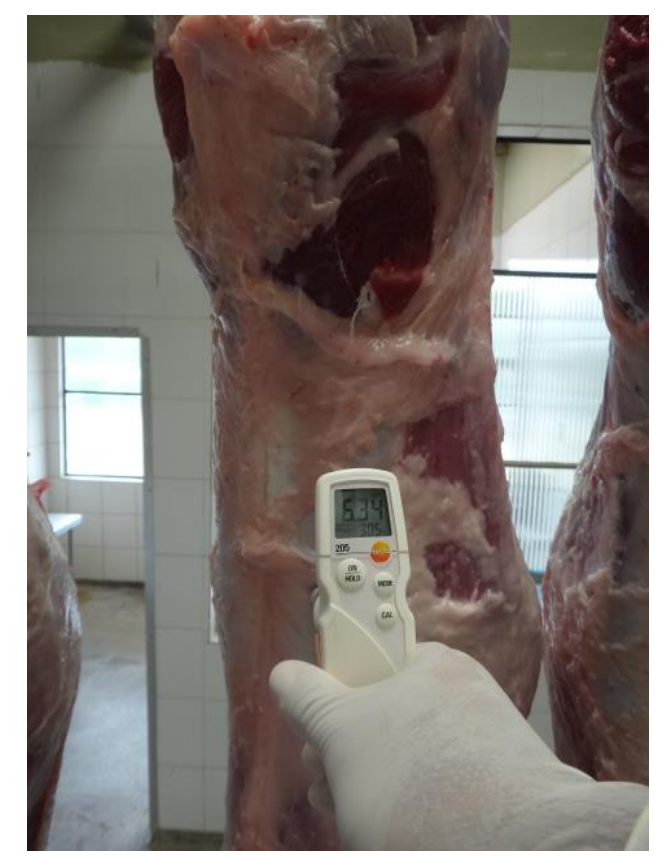

Figura 3.1: Mensuração do $\mathrm{pH}$ e temperatura no músculo Longissimus dorsi utilizando termômetro com eletrodo. Fonte: Arquivo pessoal. 
Para as análises qualitativas foram retiradas porções do músculo Longissimus dorsi, na região das $12^{\mathrm{a}}$ e $13^{\mathrm{a}}$ costelas de cada carcaça esquerda. Para a determinação da cor: luminosidade $\left(\mathrm{L}^{*}\right)$, intensidade de vermelho $\left(\mathrm{a}^{*}\right)$ e amarelo $\left(\mathrm{b}^{*}\right)$, utilizou-se o sistema CIELAB com o auxílio do colorímetro Minolta Chrome Meter CR-300 (Figura 3.2).

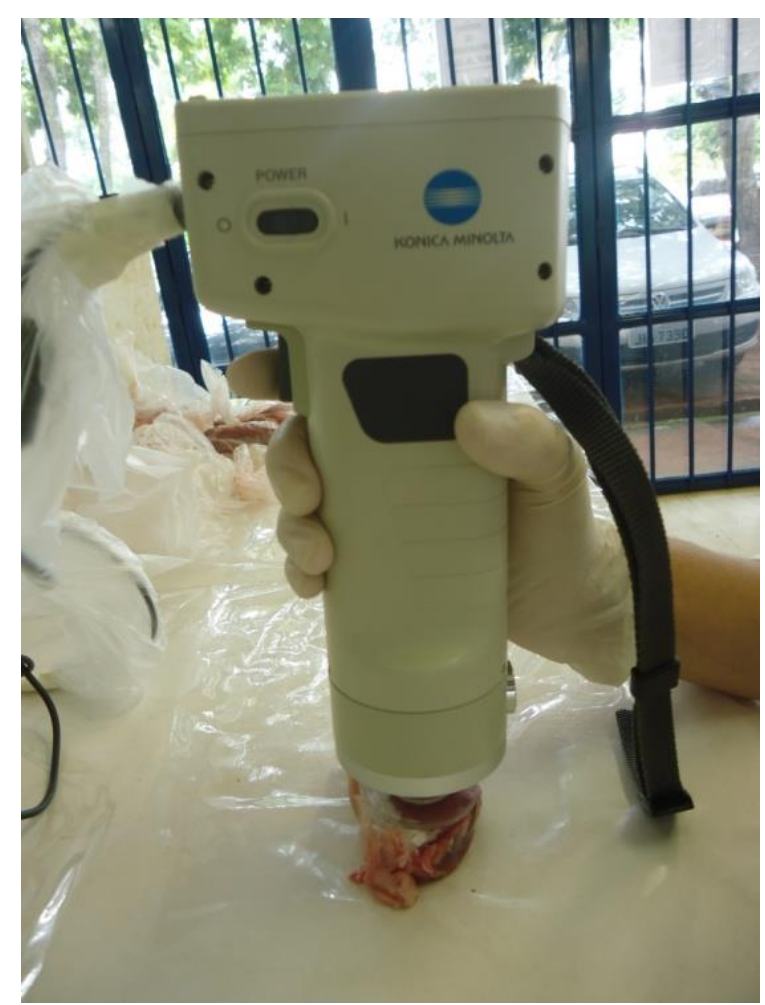

Figura 3.2: Avaliação da cor no músculo

Longissimus dorsi utilizando o colorímetro

Minolta Chrome Meter CR-300.

Fonte: Arquivo pessoal

Após a análise de cor, as amostras foram cortadas em dois bifes de aproximadamente $2,5 \mathrm{~cm}$ de espessura, pesados e assados em forno pré-aquecido, sendo a temperatura monitorada com termômetro (Figura 3.3). Após atingirem temperatura interna de $45^{\circ} \mathrm{C}$, as amostras foram retiradas do forno, viradas e recolocadas no forno para serem assadas até atingirem a temperatura final de $75^{\circ} \mathrm{C}$. As amostras foram retiradas do forno e esfriadas até atingirem a temperatura ambiente, sendo pesadas novamente para obtenção da porcentagem de perdas por cocção (PPC - relação entre o peso do bife in natura e assado). 


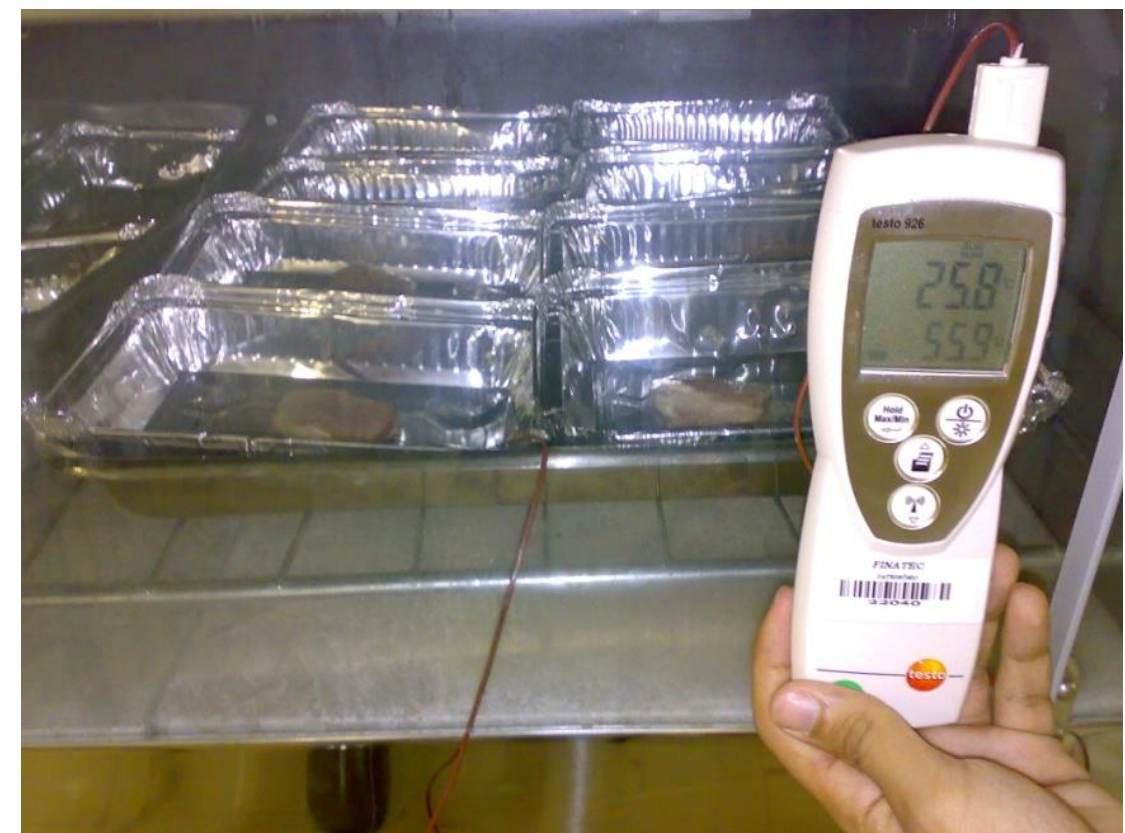

Figura 3.3: Bifes de 2,5 cm de espessura em forno pré-aquecido, monitorado com termômetro.

Fonte: Arquivo pessoal

Após serem assados, os bifes foram resfriados por 24 horas a $8^{\circ} \mathrm{C}$ e retirados três cilindros homogêneos, em torno de $1,27 \mathrm{~cm}$ de diâmetro, em cada peça (Figura 3.4). As amostras cilíndricas foram cisalhadas perpendicularmente de acordo com a orientação das fibras musculares, utilizando-se o aparelho Warner-Bratzler (Figura 3.4).

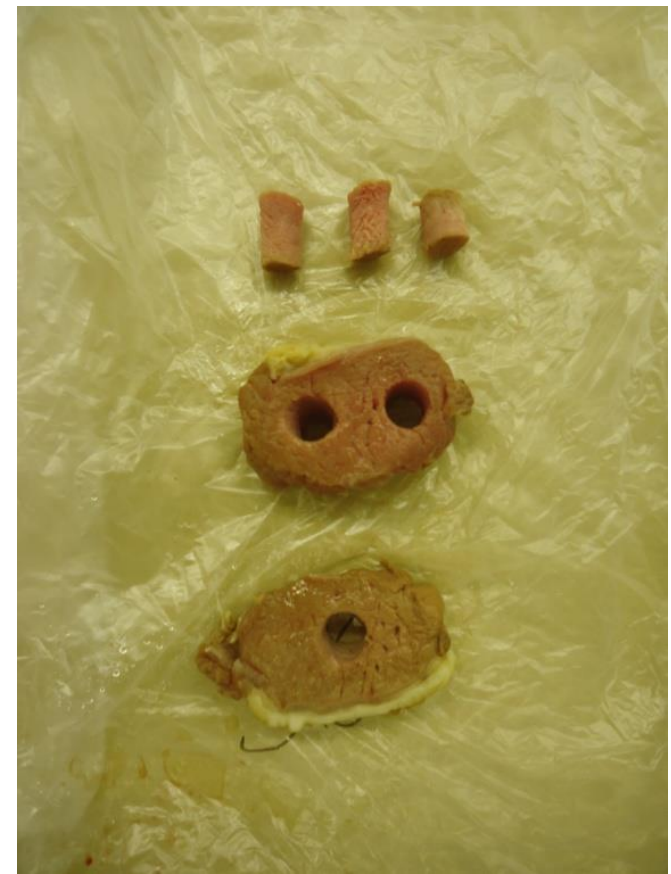

A. Cilindros homogêneos

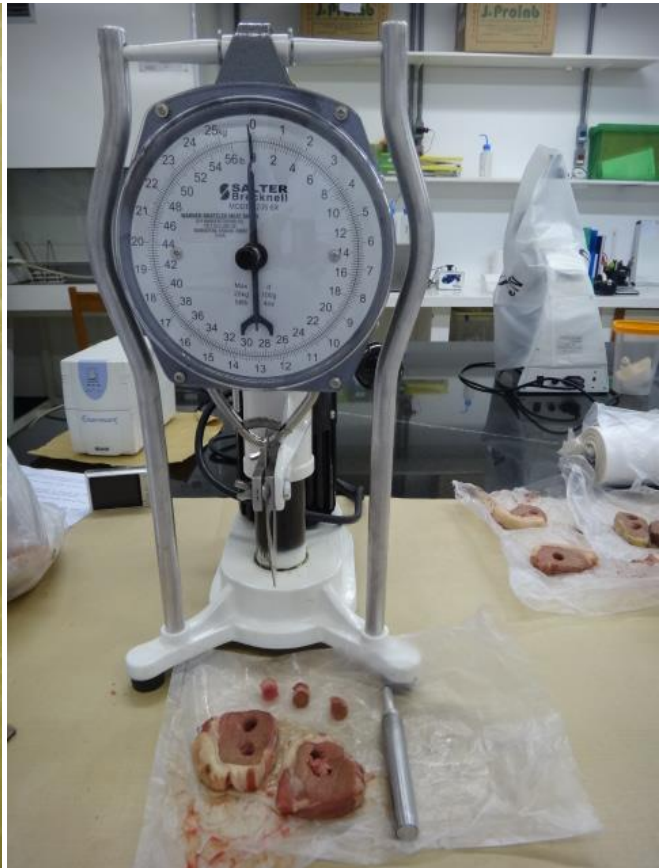

B. Aparelho Warner-Bratzler

Figura 3.4: Cilindros para avaliação da maciez da carne e aparelho para avaliação da força de cisalhamento.

Fonte: Arquivo pessoal. 
As análises de cor, perdas por cocção e força de cisalhamento foram realizadas no Laboratório de Microbiologia de Alimentos - LAMAL-UnB.

As pernas foram descongeladas em geladeira a $8^{\circ} \mathrm{C}$, por 20 horas, dentro de sacos plásticos. Após esse período, com auxílio de bisturi e faca, foi separado de cada peça: osso, músculo e gordura, para determinação das proporções de cada elemento na carcaça.

Os dados relativos ao ensaio de digestibilidade e balanço de nitrogênio foram analisados pelo procedimento PROC GLM do pacote estatístico SAS (2002). As médias foram obtidas pelo comando LSMEANS e comparadas pelo teste de Tukey, sendo as diferenças declaradas significativas quando $\mathrm{P}<0,05$. 


\section{RESULTADOS E DISCUSSÕES}

As características de $\mathrm{pH}$ inicial (45'), $\mathrm{pH}$ final (24h) e temperatura final da carcaça (Tabela 3.1) não foram influenciadas pelo grupo genético, apresentando médias de 6,33; 5,74 e 8,76 ${ }^{\circ} \mathrm{C}$, para $\mathrm{pH}$ aos 45 minutos, final e temperatura, respectivamente. Estes resultados corroboram com os obtidos por Bray et al. (1994), que não encontraram diferenças entre os genótipos Merino, Texel, Border Leicester, Poll Dorset e Siffolk, com valor médio de 5,70 para pH final. Resultado semelhante foi encontrado por Lemos Neto et al. (2001) para o pH final $(5,75)$ na carne de cordeiros cruzas Corriedale x Ile de France.

Os valores médios encontrados para o $\mathrm{pH}$ final (24h) foram de 5,74 e 5,72 para os grupos genéticos e os tipos de parto, respectivamente. Vale ressaltar que o pH final está abaixo do limite máximo ( $\mathrm{pH}$ 6) que compromete a qualidade da carne, evitando assim a formação de carne DFD (dark, firm e dry).

Tabela 3.1. Médias dos valores de $\mathrm{pH}$ inicial ( $\left.\mathrm{pH} 45^{\prime}\right)$, $\mathrm{pH}$ final ( $\left.\mathrm{pH} 24 \mathrm{~h}\right)$ e temperatura final $\left({ }^{\circ} \mathrm{C}\right)$ após abate, erro-padrão da média $(\mathrm{EPM})$ e coeficiente de variação $(\mathrm{CV})$ de cordeiros de diferentes grupos genéticos e dois tipos de parto terminados em confinamento.

\begin{tabular}{|c|c|c|c|c|c|c|c|}
\hline \multirow{2}{*}{ Variável } & \multicolumn{3}{|c|}{ Grupo Genético $^{1}$} & \multicolumn{2}{|c|}{ Tipo de Parto } & \multirow{2}{*}{ EMP } & \multirow{2}{*}{$\mathrm{CV}$} \\
\hline & White Dorper & Lacaune & Multimeat & Simples & Duplo & & \\
\hline $\mathrm{pH} 45^{\prime}$ & 6,21 & 6,42 & 6,36 & 6,30 & 6,32 & 3,20 & 2,79 \\
\hline $\mathrm{pH} 24 \mathrm{~h}$ & 5,70 & 5,72 & 5,8 & 5,71 & 5,72 & 4,80 & 2,73 \\
\hline Temp. Final $\left({ }^{\circ} \mathrm{C}\right)$ & 8,74 & 8,70 & 8,85 & 8,71 & 8,79 & 5,90 & 4,15 \\
\hline
\end{tabular}

${ }^{1}$ Grupo genético: Santa Inês x White Dorper (WD), Santa Inês x Lacaune e Santa Inês x Multimeat.

Pinheiro et al. (2009) avaliaram as características qualitativas da carne de ovinos $1 / 2$ Ile de France x $1 / 2$ Ideal abatidos aos $32 \mathrm{~kg}$ de peso vivo e observaram valores de $\mathrm{pH}$ final $(5,53)$ próximo ao obtido no presente estudo. Ekiz et al. (2009) utilizando animais Turkish merino, terminados em sistema de confinamento, apresentaram 6,65 para $\mathrm{pH}$ inicial e 
5,66 na média do pH final, estes resultados estão de acordo com os encontrados neste experimento.

$\mathrm{O}$ pH final deste estudo $(5,74)$ foi superior ao encontrado por Rech et al. (2014), utilizando animais cruzados Texel x Corriedale, terminados em confinamento e utilizando diferente dietas proteicas. Estes autores encontraram valor de $\mathrm{pH}$ igual a 5,4

A temperatura final das carcaças não diferiu entre os grupos genéticos e tipos de parto. Este resultado apresentou-se mais elevado quando comparado a outras pesquisas, podendo ser explicado devido as carcaças terem permanecido por um tempo maior fora da câmara fria para permitir a medição do $\mathrm{pH}$ e da temperatura, uma vez que havia pouco espaço para realização das mensurações dentro da câmara fria.

Não foi observada diferença entre os cruzamentos para as cores $a^{*}$ e b* e FC e PPC, reportando valores de 16,62; 4,58; $2,25 \mathrm{kgf} / \mathrm{cm}^{2}$ e 7,43\%, respectivamente (Tabela 3.2). No entanto, observou-se efeito entre os grupos genéticos para a variável $\mathrm{L}^{*}$, sendo que o grupo genético SI x Multimeat apresentou média superior $(41,82)$, enquanto que o White Dorper $(39,08)$ e Lacaune $(39,47)$ não diferiram entre si.

As intensidades de cor da carne de ovinos possuem grande variabilidade, pois, de acordo com Bressan et al. (2001), as características da cor do músculo também podem ser afetadas pela espécie, sexo, estresse pré-abate, idade do animal e tratamento pós abate.

Tabela 3.2. Médias dos valores de força de cisalhamento (FC), perdas por cocção (PPC), luminosidade $\left(\mathrm{L}^{*}\right)$, intensidade de vermelho $\left(\mathrm{a}^{*}\right)$ e intensidade de amarelo $\left(\mathrm{b}^{*}\right)$, erro-padrão da média (EPM) e coeficiente de variação $(\mathrm{CV})$ de cordeiros de diferentes grupos genéticos e dois tipos de parto terminados em confinamento.

\begin{tabular}{|c|c|c|c|c|c|c|c|}
\hline \multirow{2}{*}{ Variável } & \multicolumn{3}{|c|}{ Grupo Genético ${ }^{1}$} & \multicolumn{2}{|c|}{ Tipo de Parto } & \multirow{2}{*}{ EMP } & \multirow{2}{*}{$\mathrm{CV}$} \\
\hline & White Dorper & Lacaune & Multimeat & Simples & Duplo & & \\
\hline$\overline{\mathrm{FC}}\left(\mathrm{kgf} / \mathrm{cm}^{2}\right)$ & 2,23 & 2,14 & 2,38 & 2,3 & 2,35 & 3,0 & 17,3 \\
\hline $\operatorname{PPC}(\%)$ & 7,95 & 6,87 & 7,48 & 10,39 & 9,33 & 2,4 & 20,3 \\
\hline Cor L* & $39,08 \mathrm{~b}$ & $39,47 b$ & $41,82 \mathrm{a}$ & 40,25 & 39,99 & 6,0 & 5,10 \\
\hline Cor $\mathrm{a}^{*}$ & 16,53 & 16,97 & 16,35 & 17,02 & 15,95 & 5,3 & 8,13 \\
\hline Cor $b^{*}$ & 4,28 & 4,64 & 4,81 & $4,95 \mathrm{a}$ & $3,99 b$ & 5,5 & 9,12 \\
\hline
\end{tabular}

Médias seguidas por letras diferentes, dentro de cada linha, diferem pelo teste Tukey $(\mathrm{P}<0,05)$.

${ }^{1}$ Grupo genético: Santa Inês x White Dorper (WD), Santa Inês x Lacaune e Santa Inês x Multimeat.

O valor médio para força de cisalhamento (FC) foi de $2,25 \mathrm{kgf} / \mathrm{cm}^{2}$ e demonstra alto grau de maciez das carnes dos cordeiros (animais jovens) dos grupos genéticos estudados, podendo ser qualificado como um produto final de boa qualidade e maior aceitação 
pelo consumidor. Esta característica é uma das mais visadas e importantes para fidelizar o consumidor quanto aos produtos cárneos.

Este resultado do presente trabalho discorda com o encontrado por Grazziotin et al. (2002), que avaliando animais em sistema de confinamento, observaram forças de cisalhamento mais elevadas na carne de ovinos Texel $\left(3,18 \mathrm{kgf} / \mathrm{cm}^{2}\right)$ e Ile de France $(3,3$ $\mathrm{kgf} / \mathrm{cm}^{2}$ ) abatidos aos sete meses de idade. Esta superioridade pode ter ocorrido por causa dos animais serem abatidos com idade levemente superior aos cordeiros do presente estudo e por se tratar de raças puras especializadas na produção de carne.

Rech et al. (2014) trabalharam com animais cruzados, abatidos aos $30 \mathrm{~kg}$ apresentaram valores superiores de PPC (14,5\%) comparados ao presente estudo para os grupos genéticos $(7,43 \%)$ e valores inferiores para força de cisalhamento (FC) de 2,0 kgf/ $\mathrm{cm}^{2}$.

Resultados diferentes aos obtidos neste estudo (Tabela 3.2) foram reportados por Santello et al. (2006) para força de cisalhamento (FC) e perda por cocção (PPC), os quias observaram valor inferior $\left(1,99 \mathrm{kgf} / \mathrm{cm}^{2}\right)$ para FC e superior $(16,26 \%)$ para $\mathrm{PPC}$, ao avaliarem o efeito do sistema de terminação nas características qualitativas de carcaças de ovinos $1 / 2$ Dorset x Santa Inês.

Osório et al. (1998) verificaram efeito do genótipo nos valores de $\mathrm{L}^{*}$ e a*, no músculo Longissimus dorsi, em animais submetidos a idênticos sistemas de criação. Igualmente Bonagurio (2001) observou que a carne de cordeiros cruzados Texel x Santa Inês mostrou-se menos vermelha e mais luminosa comparada à Santa Inês.

Ekiz et al. (2009) utilizando animais provenientes de cruzamento industrial apresentaram valores superiores aos do presente estudo para os parâmetros de cor L*, a e b, de 42,$72 ; 17,50$ e 8,45, respectivamente. Rech et al. (2014) também apresentaram valor superior para o parâmetro da cor b $(4,58)$ em animais confinados.

$\mathrm{O}$ aspecto da carne fresca determina sua utilização para o comércio, sua atração para o consumidor, pois é a primeira característica a ser observada no momento da aquisição do produto, assim como sua adaptabilidade para um futuro processamento. As mudanças mais perceptíveis para o consumidor são as que podem alterar as propriedades físicas da carne, relacionadas com o frescor, influenciando diretamente sua aquisição. $\mathrm{O}$ efeito do $\mathrm{pH}$ sobre a estabilidade da coloração é importante e para isto deve-se considerar o $\mathrm{pH}$ final alcançado no rigor mortis e a queda no pré-rigor. Carnes com pHs mais elevados apresentam colorações mais escuras devido a maior absorção de luz; e as com pHs mais baixos, coloração mais clara pelo efeito contrário. 
A luminosidade $\mathrm{L}^{*}$, intensidade de amarelo $\left(\mathrm{b}^{*}\right)$, PPC e FC não foram influenciadas pelo tipo de parto, apresentando médias de 22,12;16,49; 9,85\% e 2,33 kgf/cm², respectivamente. Os valores encontrados para as variáveis FC e PPC demonstram carnes bem macias.

Observou-se diferença entre os tipos de parto para a cor a* (intensidade de vermelho), sendo que animais nascidos de parto simples apresentaram maior intensidade de vermelho na carne comparado aos animais de parto duplo, possivelmente devido a uma maior concentração de mioglobulina, que é o pigmento responsável pela coloração mais avermelhada da carne.

As médias das porcentagens do tecido muscular, tecido adiposo e tecido ósseo estão apresentados na Tabela 3.3. É necessário ressaltar que, durante a dissecação das pernas, os tecidos não identificados como músculo, osso e gordura foram classificados como outros tecidos (cartilagem, tendão), incluídos na reconstituição do peso da perna, razão pela qual a totalização dos percentuais de músculo, osso e gordura apresentados na Tabela 3.3 não atinge $100 \%$.

Não houve influência dos grupos genéticos sobre as variáveis estudadas, sendo verificados valores médios de $68,00 \%$ para o tecido muscular, 14,73\% para o tecido ósseo, $13,83 \%$ para o tecido adiposo total, sendo este representado por $72,41 \%$ por gordura subcutânea e 27,59\% pela gordura intermuscular. Já a relação músculo:osso apresentou valor médio de 4,11 e o músculo:gordura de 4,08.

Tabela 3.3. Médias das porcentagens (\%) dos tecidos constituintes da perna de cordeiros de diferentes grupos genéticos e tipos de parto, erro-padrão da média (EPM) e coeficiente de variação $(\mathrm{CV})$ de cordeiros de diferentes grupos genéticos e dois tipos de parto terminados em confinamento.

\begin{tabular}{|c|c|c|c|c|c|c|c|}
\hline \multirow{2}{*}{ Variável } & \multicolumn{3}{|c|}{ Grupo Genético ${ }^{1}$} & \multicolumn{2}{|c|}{ Tipo de Parto } & \multirow{2}{*}{ EPM } & \multirow{2}{*}{$\mathrm{CV}$} \\
\hline & White Dorper & Lacaune & Multimeat & Simples & Duplo & & \\
\hline Músculo & 69,0 & 67,1 & 67,9 & $69,0 \mathrm{a}$ & $67,5 b$ & 3,63 & 5,12 \\
\hline Osso & 14,7 & 14,9 & 14,6 & 14,68 & 13,9 & 1,56 & 7,32 \\
\hline Gordura Total & 13,9 & 13,6 & 14,0 & 13,1 & 14,0 & 3,79 & 26,50 \\
\hline Subcutânea ${ }^{2}$ & 72,5 & 71,53 & 73,21 & $68,3 b$ & $70,2 \mathrm{a}$ & 9,59 & 14,22 \\
\hline Intermuscular ${ }^{2}$ & 27,5 & 28,47 & 26,79 & 31,7 & 29,8 & 9,55 & 22,30 \\
\hline Músculo:osso & 4,2 & 3,9 & 4,23 & 4,1 & 3,76 & 1,40 & 9,01 \\
\hline Músculo:gordura & 4,17 & 3,88 & 4,19 & 4,15 & 3,78 & 2,35 & 19,95 \\
\hline
\end{tabular}

Médias seguidas por letras diferentes, dentro de cada linha, diferem pelo teste Tukey $(\mathrm{P}<0,05)$. 
${ }^{1}$ Grupo genético: Santa Inês x White Dorper (WD), Santa Inês x Lacaune e Santa Inês x Multimeat. O 100\% da composição tecidual se completa com a participação dos tecidos identificados como "outros".

Os rendimentos de músculo $(66,9 \%)$ e gordura $(10,8 \%)$ obtidos por Garcia et al. (2003) são similares aos apresentados no presente estudo, enquanto que a porcentagem de osso $(20,3 \%)$ foi um pouco superior e, consequentemente, a relação músculo:osso do presente trabalho apresentou médias superiores aos encontrados pelos autores supracitados, sendo que os mesmos trabalharam com cordeiros Suffolk terminados em creep feeding e abatidos aos 31 $\mathrm{kg}$ de peso corporal. Já o rendimento observado na gordura subcutânea $(69,1 \%)$ e na intermuscular $(30,9 \%)$ para os animais alimentados com dieta contendo cana-de-açúcar in natura foram similares aos valores observados nesse estudo.

Silva Sobrinho et al. (2002) encontraram valores similares aos do presente trabalho, avaliando efeito de diferentes relações volumoso:concentrado na composição tecidual da perna de cordeiros confinados e abatidos com $32 \mathrm{~kg}$ de peso vivo, sendo relatados valores médios de 70,69\% de músculo, 14,65\% de osso e 14,62\% de gordura.

Garcia et al. (2000), trabalhando com ovinos de diferente genótipos abatidos aos $25 \mathrm{~kg}$ registraram valores médios para a proporção de osso de $15,60 \%$, similar ao desse estudo $(14,73 \%)$ mesmo com os animais sendo abatidos com peso vivo (25 kg) inferior aos animais do presente trabalho $(39,00 \mathrm{~kg})$, podendo aferir que o crescimento ósseo finaliza precocemente não sendo influenciado pelo peso de abate, enquanto que os autores supracitados obtiveram valores inferiores de gordura $(7,18 \%)$ quando comparado ao desse estudo $(13,83)$, corroborando com trabalhos presentes na literatura que citam que, conforme o peso do animal aumenta, a porcentagem de osso na carcaça mantém e a de gordura aumenta linearmente. De acordo com Figueiró \& Benavides (1990), conforme o peso do animal aumenta, observa-se variação na proporção de osso, músculo e gordura, com diminuição da proporção de músculo e aumento de gordura.

Segundo Huidobro \& Cañeque (1994), a gordura tem papel decisivo no comportamento da maioria dos agentes da cadeia produtiva, visto que esta é um tecido de deposição tardia e que demanda um elevado consumo de energia, o que torna alto o custo de alimentação, principalmente em quantidade elevada de concentrado. Neste experimento foi observado espessura de gordura subcutânea menor devido à idade precoce dos animais experimentais.

Ao comparar diferentes genótipos, Santos et al. (2002) constataram maior relação músculo:osso $(2,65)$ na raça Santa Inês em relação à raça Bergamácia $(2,35)$. Hopkins 
et al. (1997) também concluíram que cordeiros cruzados Texel apresentaram maior índice de musculosidade, em relação aos cruzamentos Poll Dorset.

Fernandes et al. (2010) avaliando cordeiros Suffolk, terminandos em confinamento e abatidos com PV de $32 \mathrm{~kg}$, encontraram valores de 152,2; 90,3; 242,5g para gordura subcutânea, intermuscular e total, respectivamente. A relação músculo:gordura foi de 5,71 .

A gordura apresenta importante papel na qualidade e conservação da carne. Os depósitos de gordura intermuscular, subcutâneo e intramuscular influenciam diretamente na maciez e suculência, uma vez que com o aumento das gorduras intermuscular e intramuscular ocorre maior sensação destas no ato mastigatório e, com o aumento da gordura subcutânea, diminui o risco de encurtamento pelo frio (Osório et al., 2002).

Silva Sobrinho et al., (2002), trabalhando com animais cruzados Ile de France x Ideal, terminados em sistema de confinamento e abatidos aos 30 e $34 \mathrm{~kg}$, não observaram diferença $(\mathrm{P}>0,05)$ entre os tratamentos. Para os animais abatidos aos $34 \mathrm{~kg}$, obtiveram relação músculo:osso de 5,95, total de músculos de $1,271 \mathrm{~kg}$, gordura subcutânea de $193 \mathrm{~g}$ e $271 \mathrm{~g}$ do total de gordura. 


\section{CONCLUSÕES}

O cruzamento de fêmeas da raça Santa Inês com machos das raças Dorper, Lacaune ou Multimeat são indicadas para programas de cruzamento industrial para produção de cordeiros confinados, por proporcionarem características adequadas de carcaça.

Os animais provenientes de parto duplo proporcionou características qualitativas de carcaça muito satisfatórias, possibilitando o uso destes animais em sistema de terminação em confinamento. 


\section{REFERÊNCIAS BIBLIOGRÁFICAS}

BRAY, A.R.; YOUNG, S.R.; SCALES, G.H. Variation in the pH of lamb meat within and between sheep breeds. Proceedings of the New Zealand Society of Animal Production, v.54, p.201-203, 1994.

BRESSAN, C.; PRADO, O.V.; PÉREZ, J.R.O. et al. Efeito do peso ao abate de cordeiros Santa Inês e Bergamácia sobre as características físico-químicas da carne. Ciência e Tecnologia de Alimentos, v.21, n.3, p.293-303, 2001.

CARVALHO, J.B.P., PEDROSO, J.R., FIGUEIRÓ, P.R.P. 1980. Alguns fatores que afetam o rendimento de carne ovina. Revista Ciências Rurais, v.10, n.2, p.95-104.

EKIZ, B.; YILMAZ, A.; OZCAN,M.; KAPTAN, C.; HONAGLU,H. Carcass measurements and meat quality of Turkish Merino, Ramlic, Kivircik, Chios and Imroz lambs raised under an intensive production system. REVISTA, v,82, n.1, p.64-70, 2009

FERNANDES, M.A.M.; MONTEIRO, A.L.G.; ESPIRITO, C.H.; POLI, C.; BARROS, C.S.; ALMEIDA, R. Composição tecidual da carcaça e perfil de ácidos graxos da carne de cordeiros terminados a pasto ou em confinamento. Revista Brasileira de Zootecnia, v.39, n.7, p.1600-1609, 2010.

FIGUEIRÓ, P.R.P.; BENAVIDES, M.V. Produção de carne ovina. In: SIMPÓSIO DA REUNIÃO DA SOCIEDADE BRASILEIRA DE ZOOTECNIA, 27., 1990, Piracicaba. Anais... Piracicaba: Sociedade Brasileira de Zootecnia, 1990. p.16-31.

GARCIA, C.A.; MONTEIRO, A.L.G.; COSTA, C.; NERES, M.A.; ROSA, G.J.M. Medidas Objetivas e Composição Tecidual da Carcaça de Cordeiros Alimentados com Diferentes Níveis de Energia em Creep Feeding. Revista Brasileira de Zootecnia, v.32, n.6, p.13801390, 2003.

GRAZZIOTIN, M.S.; PATIÑO, H.O.; RUBENSAM, J.M. et al. Efeito da disponibilidade do pasto e da raça sobre características de carcaça e da carne de cordeiros. In: REUNIÃO ANUAL DA SOCIEDADE BRASILEIRA DE ZOOTECNIA, 39., 2002, Recife. Anais... Recife: Sociedade Brasileira de Zootecnia, 2002.1 CD-ROM. 
HUIDOBRO, F.R.; CAÑEQUE, V. Producción de carne de corderos de raza Manchega. 5. Crescimento relativo del quarto y de lós tejidos y piezas e la canal. Investigación y Sanidad Animales, n.2, v.9, p.95-108, 1994.

OSÓRIO, J.C.S.; OLIVEIRA, N.M.; OSÓRIO, M.T.M. et al. Produção de carne em cordeiros cruza Border Leicester com ovelhas Corriedale e Ideal. Revista Brasileira de Zootecnia, v.31, n.3, p.1469-1480, 2002 (suplemento).

OSÓRIO, J.C.S.; SAÑUDO, C.; OSÓRIO, M.T.M. et al. Produção de carne ovina, alternativa para o Rio Grande do Sul. Pelotas: Universidade Federal de Pelotas, 1998,136p.

PINHEIRO, R. S. B; SILVA SOBRINHO, A. G., SOUZA, H. B. A. Qualidade de carnes provenientes de cortes da carcaça de cordeiros e de ovinos adultos. Revista Brasileira de Zootecnia, v.38, n.9, p.1790-1796, 2009.

PIRES, C.C.; SILVA, L.F.; SCHLICK, F.E. et al. Cria e terminação de cordeiros confinados. Ciência Rural, v.30, n.5, p.875-880, 2000.

RECH, C.L.S.; RECH, J.L.; FISHER, V.; WIEGAND, M.M.; MOREIRA, H.L.M. Body development, carcass, and meat quality of confined lambs fed increasing levels of whole rice meal. Tropical Animal Health and Production, v. 46, n.1, p. 191-195, 2014.

SAINZ, R.D. Qualidade das carcaças e da carne ovina e caprina, In: REUNIÃO ANUAL DA SOCIEDADE BRASILEIRA DE ZOOTECNIA, 33, 1996, Fortaleza. Anais... Fortaleza: Sociedade Brasileira de Zootecnia, p.3-14, 1996.

SANTELLO, G.A.; MEXIA, A.A.; MACEDO, F.A.F. et al. Características qualitativas de carcaças de cordeiras terminadas em confinamento ou pastagem mais suplementação. In: Reunião Anual da Sociedade Brasileira de Zootecnia, 43. 2006, João Pessoa - PB. Anais... João Pessoa: Sociedade Brasileira de Zootecnia, 2006. (CD-ROM).

SANTOS, L.E.; BUENO, M.S.; CUNHA, E.A.; LEMOS NETO, M.J. Desempenho e características de carcaça de cordeiros Santa Inês e cruzados com raças especializadas para corte. 2002. Disponível em: <http://www.ovinosbrasil.com>. Acesso em: 15/08/2014.

SILVA SOBRINHO, A.G.; MACHADO, M.R.F.; GASTALDI, K.A.; GARCIA, C.A. Efeitos da Relação Volumoso:Concentrado e do Peso ao Abate sobre os Componentes da Perna de Cordeiros Ile de France $x$ Ideal Confinados. Revista Brasileira de Zootecnia, v.31, n.2, p.1017-1023, 2002 (suplemento). 